\title{
Morphology, microanatomy and sequence data of Sclerolinum contortum (Siboglindae, Annelida) of the Gulf of Mexico
}

\author{
Irmgard Eichinger • Stéphane Hourdez • Monika Bright
}

Received: 4 July 2012 / Accepted: 13 December 2012 /Published online: 24 January 2013

(C) The Author(s) 2013. This article is published with open access at Springerlink.com

\begin{abstract}
Sclerolinum is a small genus of Siboglinidae (Annelida) living in an obligate mutualistic association with thiotrophic bacteria as adults. Its taxonomic position, based on morphology, has been controversial; however, molecular data point to a sister taxa relationship with vestimentiferans. 16S rRNA gene sequencing and comparative morphology revealed that the studied population from deep-sea hydrocarbon seeps of the Gulf of Mexico belongs to Sclerolinum contortum known from the Arctic Sea. Since no anatomical and microanatomical studies have been published yet, we conducted such a study on $S$. contortum using serial sectioning and light and transmission electron microscopy. We show that the Sclerolinum body, divided into a head, trunk, and opisthosoma, is very similar to that of the vestimentiferans, and therefore we propose that the body regions are homologous in both taxa.
\end{abstract}

Keywords Sclerolinum $\cdot$ Siboglinidae $\cdot$ Symbiosis · Ultrastructure

I. Eichinger $(\triangle) \cdot$ M. Bright

Department of Marine Biology, University of Vienna,

Althanstr. 14,

1090 Vienna, Austria

e-mail: irmi.eichinger@kabsi.at

S. Hourdez

Station Biologique de Roscoff, UMR 7144, CNRS, Equipe

Génétique des Adaptations aux Milieux Extrêmes,

29680 Roscoff, France

\section{S. Hourdez}

Station Biologique de Roscoff, UMR 7144, Université Pierre et Marie Curie, Equipe Génétique des Adaptations aux Milieux Extrêmes, 29680 Roscoff, France

\section{Introduction}

Sclerolinum is a small genus of slender marine tubeworms, which together with vestimentiferans, Osedax, and frenulates forms the monophyletic annelid family, Siboglinidae Caullery, 1914 (McHugh 1997; Rouse and Fauchald 1997; Rouse et al. 2004). They are renowned for their symbiotic lifestyle in a variety of reducing habitats since all adult representatives-except for Osedax dwarf males (Rouse et al. 2004) - rely completely on endosymbiotic bacteria. They reduce their digestive system during ontogeny and develop a new organ, called the trophosome, to accommodate and provide their chemoautotrophic (Felbeck 1981; Felbeck et al. 1981; Lösekann et al. 2008; Southward et al. 1981) or heterotrophic symbionts (Goffredi et al. 2007, 2005).

Sclerolinum species occur in a wide range of deep-sea environments from less than 500 to about $2,000 \mathrm{~m}$ depth. Most of the seven described species (Ivanov and Selivanova 1992; Smirnov 2000; Southward 1961, 1972; Webb 1964c) dwell either on decaying organic materials like sunken wood or in sulfidic sediments (Smirnov 2000). Sclerolinum contortum Smirnov 2000, is reported from the arctic, cold seep Haakon Mosby Mud Volcano, cold seeps of the Storegga Slide in the Norwegian Sea (Lazar et al. 2010), and a hydrothermal vent field of the Arctic Mid-Ocean Ridge (Pedersen et al. 2010). Other not yet described species have been found at cold seeps in the Sea of Okhotsk (Sahling et al. 2003) and in hydrothermal vent sediments of Antarctica (Sahling et al. 2005).

The genus Sclerolinum has challenged scientists since its discovery. Its organization fits well to neither the known frenulates nor the later discovered vestimentiferans. Discussed as the most basal (Southward 1999; Webb 1964b) or a more derived siboglinid (Ivanov 1994; Southward 1993), its classification switched from genus to 
subclass rank. Southward (1961) described the first Sclerolinum species and established the genus Sclerolinum within the frenulate family Polybrachiidae. Later, considering the peculiarities of Sclerolinum, a new family, Sclerolinidae (Webb 1964b), and even a new monogeneric subclass, Monilifera (Ivanov 1991), were created with equal rank to frenulates and vestimentiferans. Today, Sclerolinum is considered the sister group to vestimentiferans because of molecular and morphological data (Halanych et al. 2001; Hilário et al. 2011; Meunier et al. 2010; Rouse 2001; Zrzavý et al. 2009), but see also Schulze (2003) and Rousset et al. (2004). Osedax is placed as sister group to Sclerolinum plus vestimentiferans. Frenulates are sister to all of them (Hilário et al. 2011; Rouse et al. 2004); however, the position of Osedax is ambiguous in the study of Zrzavý et al. (2009).

Siboglinids have a body divided into different regions. In frenulates, a cephalic lobe (prostomium sensu Rouse 2001), a forepart, a trunk with specialized regions such as an anterior metameric region, and an opisthosoma are distinguished (Southward 1993). Osedax females are composed of a crown, a trunk, and an ovisac with roots (Rouse et al. 2004). In Sclerolinum a cephalic lobe, a forepart, a trunk, and an opisthosoma are found (Southward et al. 2005). Vestimentiferan bodies are composed of an obturacular region, a vestimentum, a trunk, and an opisthosoma (Gardiner and Jones 1993).

Vexingly, Sclerolinum lacks a visible external demarcation between the forepart and the trunk. The existence of an internal diaphragm is still in discussion. A muscular diaphragm separating the forepart from the trunk is formed during larval development in frenulates (Bakke 1977; Callsen-Cencic and Flügel 1995; Ivanov 1975). Such a diaphragm is also mentioned in two adult Sclerolinum species (Ivanov 1991; Southward 1961). In addition, Southward (1961) separated an anteriorly located metameric trunk region from the posterior trunk by the presence of paired lateral ridges occupied by large glands in the former body region. Later, the metameric region was mentioned as dorsally grooved and ventrally ciliated (Southward 1972; Webb 1964c).

Although we lack any knowledge of the internal anatomy of Sclerolinum to date, its body regions have been homologized with those of other siboglinid taxa: the forepart with the frenulate forepart and the vestimentum of vestimentiferans (Hilário et al. 2011; Rouse 2001; Rouse and Pleijel 2001; Rousset et al. 2004; Southward et al. 2005; Webb and Ganga 1980) and the metameric region with the metameric trunk region of frenulates (Southward 1972). The presence or absence of the metameric region has been used as a character for cladistic analyses (Rouse 2001; Rousset et al. 2004; Schulze 2003). The opisthosoma is similarly organized in frenulates, vestimentiferans, and Sclerolinum and regarded as homologous region in all three taxa.
We investigated a Sclerolinum population from deep-sea hydrocarbon seeps in the Gulf of Mexico (GoM) to improve our knowledge of this highly debated but little studied siboglinid taxon. We used 16S rRNA gene sequencing and comparative sequence analyses to characterize the host species by molecular techniques and confirm its position in relation to other Siboglinidae. We used light and electron microscopy for measurements and description of the external morphology, but our main intention was to describe the anatomy and microanatomy in order to provide, for the first time, comparative data of one representative of this genus. We found high anatomical similarities between the vestimentiferan and Sclerolinum body organization, clearly pointing to a sister taxa relationship, as previously suggested by molecular (Halanych et al. 2001; Rouse et al. 2004) and morphological (Rouse 2001) approaches, as well as combined studies (Rousset et al. 2004; Zrzavý et al. 2009).

\section{Materials and methods}

During the "Expedition to the Deep Slope" (chief scientist C.R. Fisher) with the NOAA R/V Ronald H. Brown in June 2007, Sclerolinum aggregations dwelling at the hydrocarbon seeps in the GoM were sampled with cores of $30 \mathrm{~cm}$ or $50 \mathrm{~cm}$ length at three sites (WR269, AC818, AC601) at depths ranging from 2,000 to $2,700 \mathrm{~m}$. The samples were recovered with the ROV Jason during dives J2-275, J2-282, and $\mathrm{J} 2-283$.

In addition, for genetic studies, reference specimens of $S$. contortum from the Northeast Atlantic were collected during the VICKING cruise with the ROV Victor (dives 275 and 277). Sequencing was performed on one specimen from Storegga Northeast $\left(64^{\circ} 45.27^{\prime} \mathrm{N}, 4^{\circ} 58.87^{\prime} \mathrm{E}, 745 \mathrm{~m}\right.$ depth) and one specimen from Haakon Mosby Mud Volcano (HMMV, $72^{\circ} 00.34^{\prime} \mathrm{N}, 14^{\circ} 58.87^{\prime} \mathrm{E}, 1264 \mathrm{~m}$ depth). All samples for subsequent molecular methods were fixed in $100 \%$ ethanol and stored at $4{ }^{\circ} \mathrm{C}$. Fixation, embedding, cutting, and staining procedures for light and electron microscopy on GoM animals are described in Eichinger et al. (2011).

16S rRNA gene sequencing and phylogenetic analyses of the host

After removal of excess ethanol, total DNA was isolated following a CTAB + PVPP extraction protocol (Doyle and Doyle 1987). The mitochondrial gene coding for the ribosomal 16S RNA was amplified using the primers designed by Palumbi (1996). The optimal PCR cycling parameters were 1 cycle: $3 \mathrm{mn} / 96{ }^{\circ} \mathrm{C} ; 35$ cycles: $1 \mathrm{mn} / 96^{\circ} \mathrm{C}, 1.15 \mathrm{mn} /$ $50{ }^{\circ} \mathrm{C}, 1 \mathrm{mn} / 72{ }^{\circ} \mathrm{C}$; 1 cycle: $10 \mathrm{mn} / 72{ }^{\circ} \mathrm{C}$. PCR products were visualized after electrophoresis on $1.5 \%$ agarose gels 
containing ethidium bromide under UV light. Both DNA strands were directly sequenced with BigDye Terminator v. 3.1 (Applied Biosystems) on an ABI $3130 \mathrm{XL}$ automated sequencer. The two mt16S sequence fragments for each species were assembled and edited in CodonCode Aligner (CodonCode) to generate a continuous ca. 500-base pair fragment. Sequence alignment was performed using Clustal W and checked visually. The phylogenetic tree was generated with MEGA version 5 (Tamura et al. 2011), using a Kimura-2-paramater distance calculation and a neighborjoining tree reconstruction. Robustness of tree nodes was tested by bootstrapping the data with 1,000 pseudoreplicates. Sequences of representatives from all major siboglinid taxa were included in the analysis; accession numbers can be found in Fig. 1. The Oweniidae Myriochele was used as an outgroup.

Light and electron microscopy

Five complete worms and several worm fragments were fixed for light microscopy and used for the description of the external morphology. One complete female was fixed for light microscopy, cut into small pieces, embedded, and cut into a series of $1-\mu \mathrm{m}$ semithin sections. Several samples of the female and male trunk region, one opisthosoma, and one anterior end of a male were fixed, embedded, cut, and stained for transmission electron microscopy. Only the anterior end of the male was treated differently since it was cut into a series of $1-\mu \mathrm{m}$ semithin sections alternated with ultrathin sections.

All sections were made on a Reichert Ultracut S microtome. Semithin sections were viewed with a Zeiss Axio Imager A1 light microscope, and ultrathin sections were analyzed with a Zeiss EM 902 transmission electron microscope.

Measurements of taxonomic characters and statistical analyses

Taxonomic characters were measured by using Image $\mathrm{J}$ software, version $1.40 \mathrm{~g}$. Correlations of the length of the worms with body diameters, measured at different body regions, were statistically tested using Excel (Microsoft) by creating regression plots.

\section{Results}

mt16s gene phylogeny of the host

The phylogeny of the Siboglinidae based on the mitochondrial 16S fragment sequenced yielded a very well resolved tree, with strong support for the major clades (Fig. 1).
Sclerolinum brattstromi and S. contortum form a very highly supported monophyletic sister group to a vestimentiferan clade (comprising cold-seep and hydrothermal-vent species). Osedax is sister to these clades, and the frenulates are sister to all other siboglinid species. Based on this marker, the GoM Sclerolinum is indistinguishable from the Northeast Atlantic (HMMV and Storegga) specimens of $S$. contortum (100\% identity with the HMMV sequence). They form a very strongly supported clade, clearly distinct from Sclerolinum brattstromi. Divergence levels are similar to those observed for other siboglinid species (e.g., Osedax frankpressi).

Tube

The tubes were approximately twice as long as the inhabiting worms (Fig. 2). The maximal tube diameter ranged from $0.35 \mathrm{~mm}$ to $0.61 \mathrm{~mm}(n=5)$. The tubeworms mostly live buried in mud, only the anterior curled and transparent ends of the tubes extending into the surrounding water. The tips of these anterior ends were frail and easily collapsed (Fig. 3a). The rest of the tubes were more or less straight, yellowish to brownish and firm, except for the posterior parts, which were colorless, extremely thin walled, soft, and frayed (Fig. 2).

\section{External morphology}

The body was divided into the cephalic lobe, forepart with two tentacles, trunk, and opisthosoma. The genital openings marked the beginning of the trunk according to Webb and Ganga (1980). This correlated with the beginning of the randomly distributed cuticular plaques of the trunk.

Table 1 contains the measurements and morphological characters of $S$. contortum GoM. The animals ranged from $54 \mathrm{~mm}$ to $86 \mathrm{~mm}$ in length, measured from the tip of the cephalic lobe to the end of the opisthosoma, and from $0.27 \mathrm{~mm}$ to $0.45 \mathrm{~mm}$ in diameter, measured at the first opisthosomal septum $(n=5)$. These values correlated, while diameters measured at other body regions, for example, at the anterior edge of the bridle, did not correlate with the length.

The worms had a very small cephalic lobe, with an extension of $68-78 \mu \mathrm{m}$ lacking a separation from the forepart, which was characterized by densely packed glands and a deep narrow dorsal furrow shaped like an upside down Y (Fig. 4bd). The frenulum was located approximately $0.48 \mathrm{~mm}$ posterior to the tip of the cephalic lobe and consisted of 12 to 20 roundish to elongated cuticular plaques. These plaques were arranged either as two dense, arched rows extending from dorsal to ventral (Fig. 3b) or in a more scattered manner (Fig. 3c). There was a large variation in size of the frenular plaques from $11-27 \mu \mathrm{m}$ in width and $21-85 \mu \mathrm{m}$ in length. Neither the size nor the number of the frenular plaques 


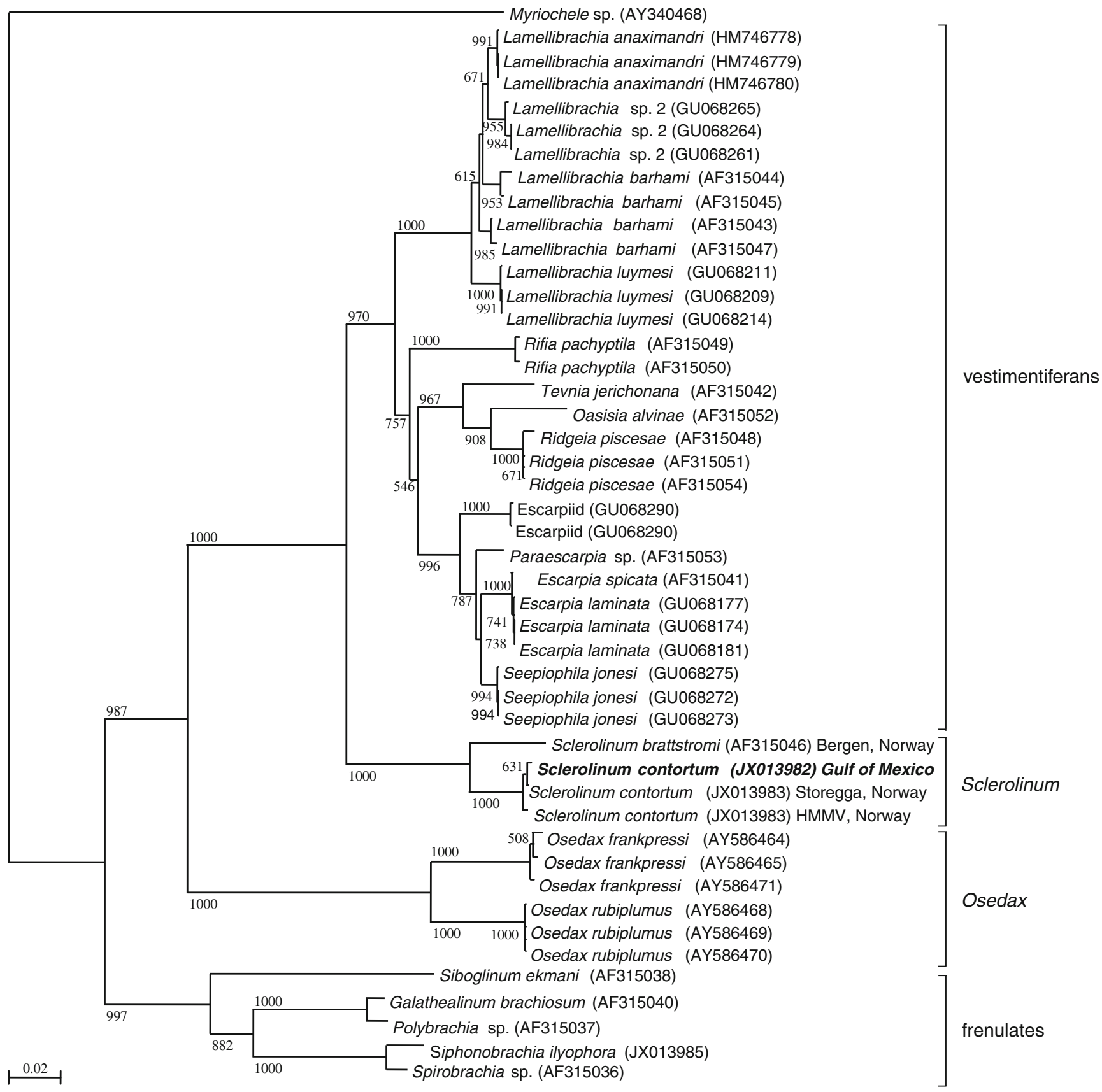

Fig. 1 Phylogenetic tree of the Siboglinidae, including species of vestimentiferans, Sclerolinum, Osedax, and frenulates. Myriochele sp. (Polychaeta; Oweniidae) was used as an outgroup. The tree was built by neighbor-joining on a Kimura-2-Parameter distance calculated on a 471-bp alignment of a mitochondrial 16S rRNA fragment. Bootstrap values given only when greater than 500 out of 1,000 replicates. Accession numbers are given between parentheses for each branch. Location of collection given for Sclerolinum only

forming two ciliated grooves, each ending with a genital papilla (corresponding to the openings of the sperm ducts), slightly posterior to the ventral ciliated field (Fig. 5b). Congruently, the anterior end of the trunk was easily recognizable by scattered, conspicuous, oval plaques situated on top of epidermal papillae. They extended after the end of the dorsal furrow to the first opisthosomal segment and were restricted to the trunk (Fig. 3d). 
Fig. 2 Tubes of Sclerolinum contortum GoM with characteristic anterior curled and posterior straight part

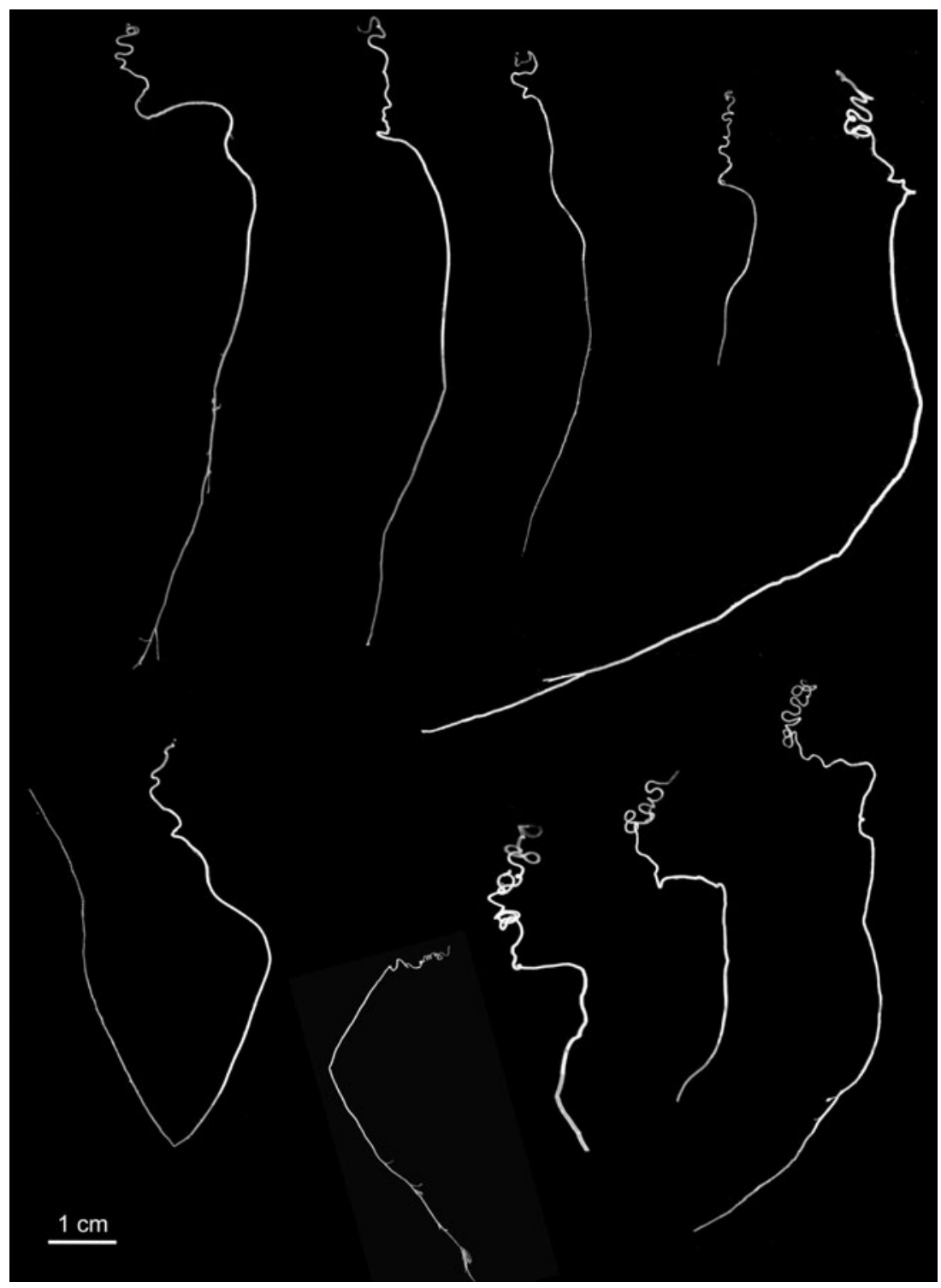

Only the anterior trunk region had prominent lateral epidermal papillae devoid of plaques, which were the openings of loosely arranged large pyriform glands (Fig. 6a). At the posterior margin of the trunk were one to two rings of uncini forming the girdles.

The opisthosoma consisted of 13 to 16 segments and ranged in length between $1.4-1.8 \mathrm{~mm}$. Each segment exhibited an incomplete ring of uncini devoid of chaetae middorsally and midventrally. These rings became more incomplete at the posterior segments (Fig. 3e, f).

The measured five complete worms did not represent the largest specimens in the Sclerolinum aggregations we sampled. The largest found opisthosoma was $2.7 \mathrm{~mm}$ long, had a diameter of $0.54 \mathrm{~mm}$ at the first septum, and a total number of 19 segments. Assuming body proportions similar to those of the complete worms studied, this would correspond to a total length of $100 \mathrm{~mm}$.
General internal organization

The two tentacles were free of pinnules and ciliated cells. We located two longitudinal blood vessels and a central coelomic cavity, which was occluded by mesenchyme at the base of each tentacle (Fig. 4a, b).

The cephalic lobe was a very short ventral epidermal extension of the forepart containing the brain at its base. It had no coelomic cavity, muscle cells, or blood vessels, but was invaded by blood lacunae (Fig. 4b). The compact forepart also lacked a visible coelomic cavity. The cavity was occupied by the pyriform glands, mesoderm, and dorsal and ventral blood vessels. The ventral nerve cord bifurcated around the ventral ciliated field (Fig. 4c, d).

The trunk was mostly occupied by the trophosome, the gonads, and pyriform glands. The paired coelomic cavities 

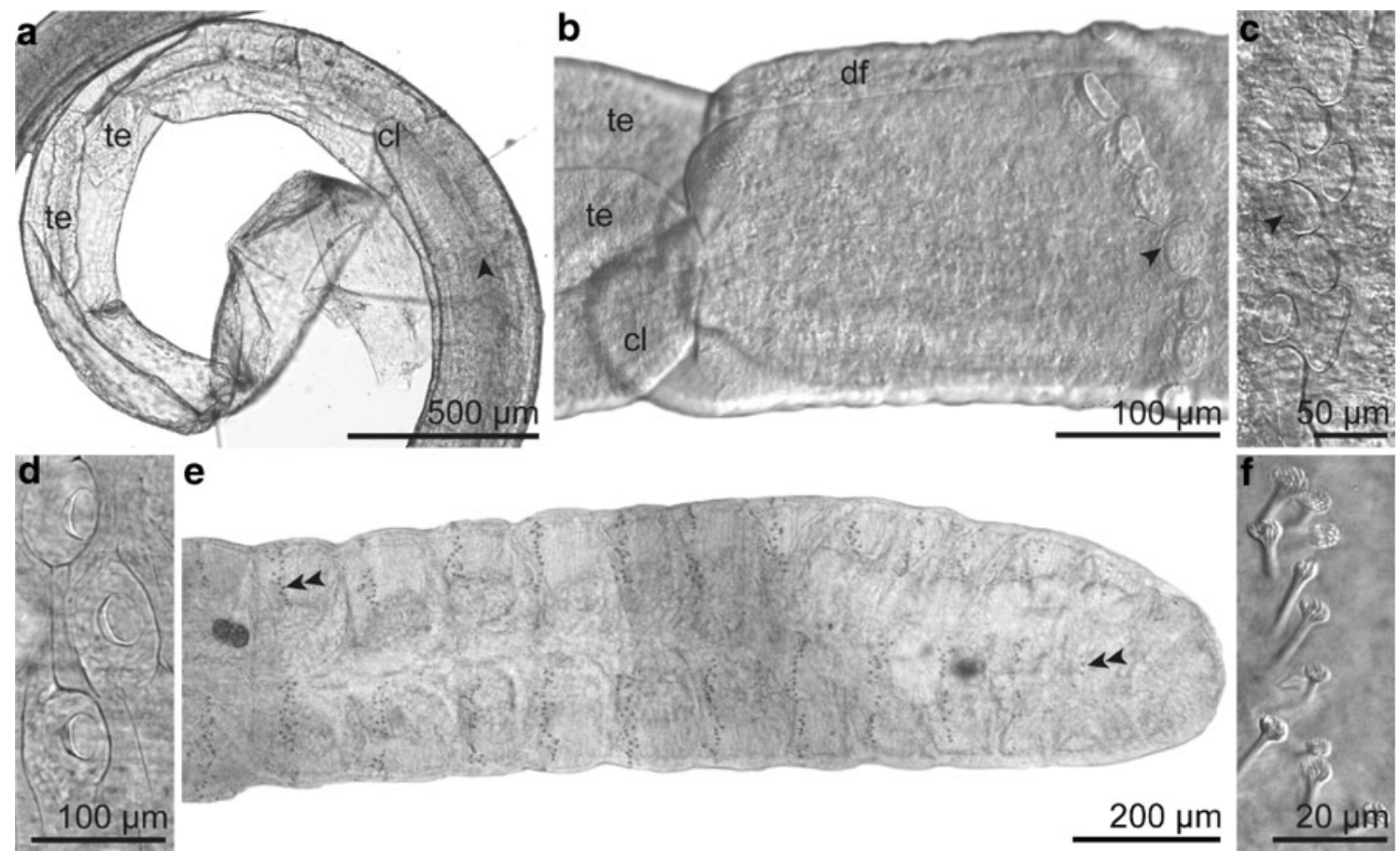

Fig. 3 General morphology (LM). a Anterior end of the worm within the transparent and collapsed anterior part of the tube. b Forepart with dorsal furrow and frenulum consisting of cuticular plaques arranged in a row. $\mathbf{c}$ Frenulum of other specimen consisting of scattered cuticular

were reduced to small spaces. The dorsal and ventral blood vessels were suspended by the mesenteries (Fig. 6a-c). A single female ovary or paired male testes were connected plaques. d Cuticular plaques of the trunk. e Multisegmented opisthosoma with rings of uncini (double arrowhead). $\mathbf{f}$ Uncini of opisthosoma. Abbreviations: $\mathrm{cl}=$ cephalic lobe; $\mathrm{df}=$ dorsal furrow; te $=$ tentacle; arrowhead $=$ frenular plaque; double arrowhead $=$ uncini

ventrally to the mesentery. The ventral nerve cord extended over the whole length of the trunk. Several times along the posterior trunk both the epidermis and the longitudinal
Table 1 Comparison of morphological characters of the Sclerolinum contortum populations from the Haakon Mosby Mud Volcano (HMMV) and the Gulf of Mexico (GoM) modified from Smirnov 2000

Abbreviations: $\mathrm{d}=$ dorsal; 1 = lateral; $\mathrm{v}=$ ventral

\begin{tabular}{lll}
\hline & $\begin{array}{l}\text { S. contortum HMMV } \\
n=18\end{array}$ & $\begin{array}{l}\text { S. contortum GoM } \\
n=5\end{array}$ \\
\hline Tube, general character & $\begin{array}{l}\text { Regularly bent anteriorly, } \\
\text { straight posteriorly }\end{array}$ & $\begin{array}{l}\text { Regularly bent anteriorly, } \\
\text { straight posteriorly }\end{array}$ \\
$\begin{array}{l}\text { Distance from apex of cephalic lobe to } \\
\text { frenulum (mm) }\end{array}$ & $0.27-0.3$ & $0.32-0.59$ \\
Arrangement of frenular plaques & Dense row & Dense row/scattered \\
Frenulum, position & d-1-(v) & d-1-v \\
Number of frenular plaques & $10-14$ & $12-20$ \\
Frenular plaques, shape & Oval & Roundish to oval \\
Frenular plaques, diameter $(\mu \mathrm{m})$ & $22-41$ & $21-85$ \\
Forsal furrow & Deep, narrow & Deep, narrow \\
Plaques of trunk, diameter $(\mu \mathrm{m})$ & $29-41$ & $30-50$ \\
Transition between forepart and trunk & Abrupt & Abrupt \\
Forepart length (mm) & $2.3-4.8$ & $3.5-6.4$ \\
Trunk length (mm) & $30-50$ & $47.9-80.6$ \\
Opisthosoma length (mm) & $0.45-0.6$ & $1.4-1.8$ \\
Opisthosoma number of segments & $3-5$ & $13-16$ \\
Uncini of opisthosoma, diameter $(\mu \mathrm{m})$ & $5.5-6.3$ & $4.5-6.5$ \\
Habitat & Mud & Mud \\
\hline
\end{tabular}



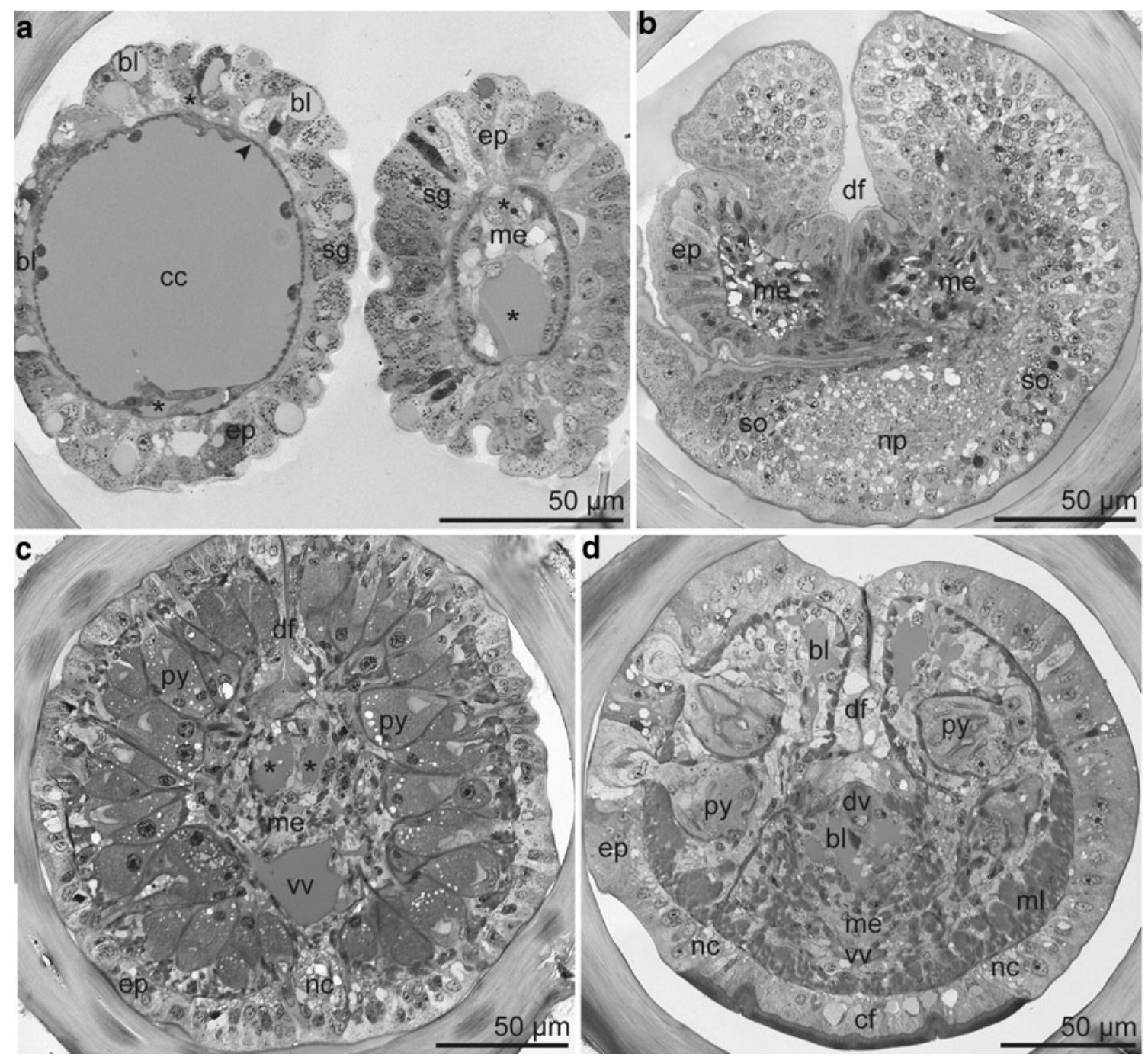

Fig. 4 Semithin section series of tentacles and forepart. a Left tentacle at distal position with vascularized epidermis overlaying a singlelayered myoepithelium (arrowhead) surrounding a central coelomic cavity. Right tentacle at proximal position with mesenchyme filling the coelomic cavity. Each tentacle with two blood vessels (asterisk). b Base of cephalic lobe and of tentacles and beginning of the dorsal furrow; cephalic lobe with the brain consisting of central neuropil and peripheral somata; tentacles with mesodermal strands. c Forepart anterior to the frenulum with densely packed pyriform glands, single ventral nerve cord, and paired dorsal blood vessels (asterisk). d Forepart posterior to the frenulum with pyriform glands loosely distributed from dorsal to lateral and ventral nerve encasing the ciliated field. Abbreviations: $\mathrm{bl}=$ blood lacuna; $\mathrm{cc}=$ coelomic cavity; $\mathrm{cf}=$ ciliated field; $\mathrm{ep}=$ epidermis; $\mathrm{df}=$ dorsal furrow; $\mathrm{dv}=$ dorsal blood vessel; me $=$ mesoderm; $\mathrm{ml}=$ body wall muscle layer; $\mathrm{nc}=$ nerve cord $; \mathrm{np}=$ neuropil; $\mathrm{py}=$ pyriform gland; $\mathrm{sg}=$ single gland cell; $\mathrm{so}=$ somata; $\mathrm{vv}=$ ventral blood vessel

\section{Epidermal structures}

Apically, the epidermal supportive cells possessed microvilli embedded within a thin cuticle and laid on a basal matrix (Fig. 8a). Multiciliated cells formed a broad ventral ciliated field (Fig. 8b). In males, multiciliated supportive cells were part of the epithelium of the posterior dorsal furrow (Fig. 8c) and constituted the genital grooves extending from the dorsal furrow to the genital papillae (Fig. 5b). Although sensory cells were not specifically sought, none were noticed. 


\section{Nervous system}

The intraepidermal nervous system consisted of the brain located at the base of the cephalic lobe, a main ventral nerve cord extending through the entire length of the body, and numerous small nerves. At the transition from the cephalic lobe to the forepart, the neurons forming the brain were differentiated into a central neuropil surrounded by somata except for the dorsal side (Fig. 4b). All neurites were located basally to the epidermal cells with the basal matrix underlining the nervous cells. Small nerves ran from the tentacles to the brain. Neurites originating from the brain extended laterally at the beginning of the forepart. A single ventral nerve cord continued from the brain (Fig. 4c) and bifurcated around the ventral ciliated field, which was provided with many small nerves (Figs. 4d, 8b), and extended over the whole trunk (Fig. 8d). Within the opisthosoma, the nerve broadened, forming a ventral nerve field, which concentrated at the end of the opisthosoma into one narrow cord again. Over the whole length of the nerve cord we found no giant axons.

\section{Epidermal glands}

Single gland cells with electron-dense granules were distributed in the epidermis over the whole body, but were conspicuously dense on the inner face of the tentacles (Fig. 4a).

Multicellular pyriform glands sensu Ivanov (1963) consisted of a duct and a sac-like glandular region. They were composed of multiple secretory cells with microvilli apically facing the glandular lumen. These glands protruded into the interior of the forepart and the trunk. Although the principal composition of these glands was similar, the occurrence, density, and microanatomy varied regionally.

Anterior to the frenulum, these glands were extremely densely packed across the body except midventrally, where the nerve cord was located (Fig. 4c). They were characterized by an extensive rough endoplasmic reticulum (rER) and electron-light, amorphous secretion products (Fig. 9a, b). In between the frenulum and the ventral ciliary filed, they were also densely packed, but full of electron-dark granules, Golgi complex, and rER (Fig. 9c, d). With the beginning of the ventral ciliated field, the glands became larger, had a looser dorsolateral distribution (Fig. 4d), and were composed of glandular cells containing rER, Golgi complex, and different kinds of granules (Fig. 9e). All glands of the forepart had openings lacking epidermal elevations, and they never opened into the dorsal furrow.

The pyriform glands of the trunk were arranged laterally in the anterior trunk region and loosely scattered in the posterior trunk region. Only the anteriorly located glands opened within lateral epidermal papillae (Fig. 6a). All glands of the trunk cytologically resembled the glands of the ciliated region; however, some contained intracellular bacteria of unknown identity (Fig. 9f).

Another type of multicellular gland was found in the opisthosoma. Associated with the anterior face of the septa and provided by blood lacunae, they reached into the

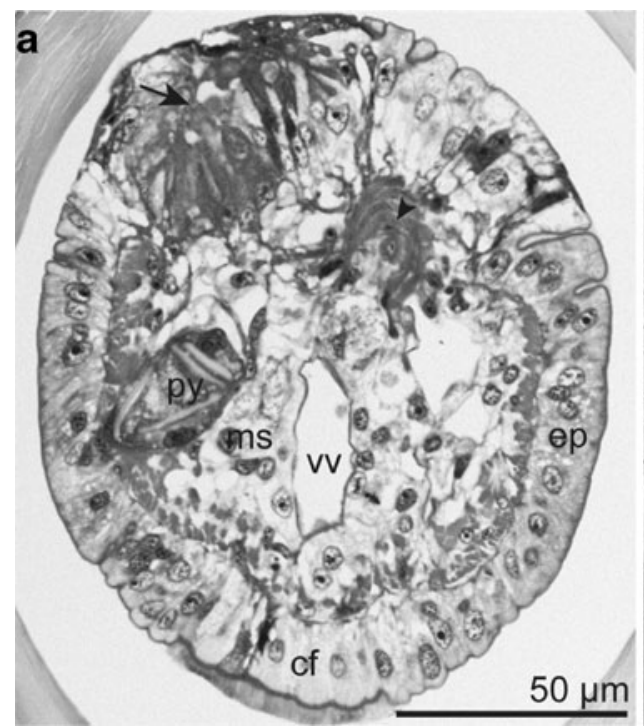

Fig. 5 Region of genital openings and muscles encircling the dorsal blood vessel (arrowhead) (LM). a Transverse section of female immediately posterior to the dorsal furrow showing the opening of a single oviduct (arrow). b Transverse section of a male at the end of the ciliated grooves showing the genital papillae and the openings of the

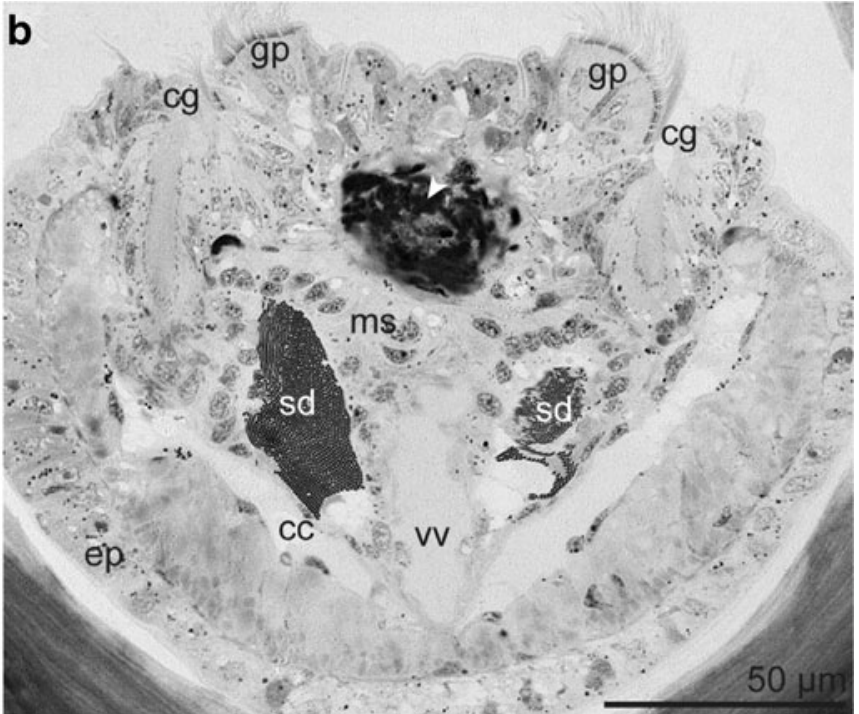

sperm ducts. Abbreviations: $\mathrm{cc}=$ coelomic cavity; $\mathrm{cf}=$ ciliated field; $\mathrm{cg}=$ ciliated groove; $\mathrm{ep}=$ epidermis; $\mathrm{gp}=$ genital papilla; $\mathrm{ms}=$ mesenchyme; py $=$ pyriform gland; $\mathrm{sd}=$ sperm duct; $\mathrm{vv}=$ ventral blood vessel 

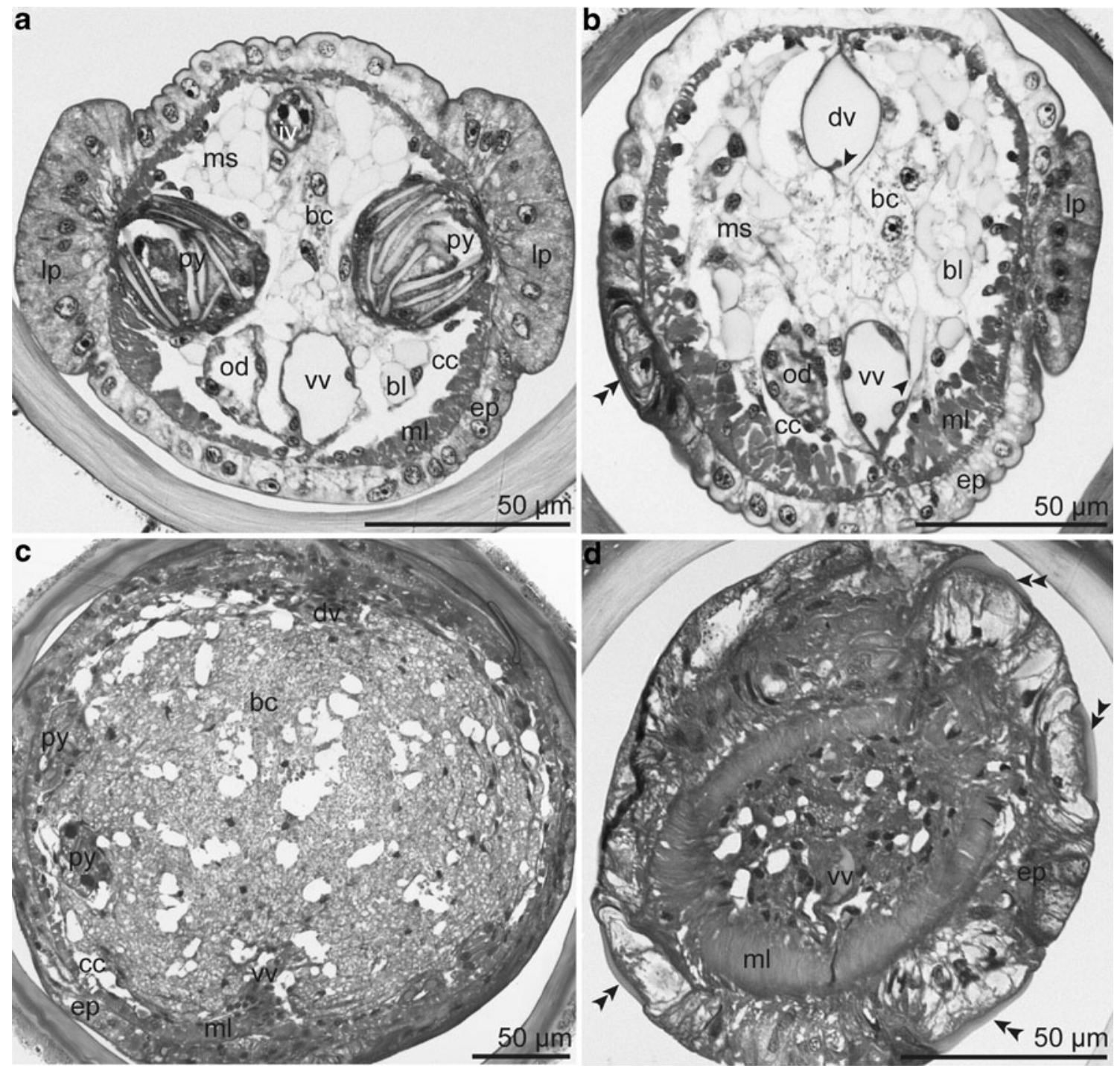

Fig. 6 Semithin section series of anterior trunk region with only a few bacteriocytes embedded within a non-symbiotic mesenchyme (a-b) and posterior trunk region with massive bacteriocyte tissue (c-d). a Lateral pyriform glands opening into epidermal papillae devoid of cuticular plaques; dorsal blood vessel clogged by the intravasal body. b Ventral and dorsal blood vessel connecting to blood lacunae (arrowhead); epidermis with papilla bearing cuticular plaque (double arrowhead). c Posterior end of the trophosome showing bacteriocytes filling the body cavity. $\mathbf{d}$ Thickening of the epidermis and longitudinal muscle layer in combination with dense arrangement of cuticular plaques (double arrowhead). Abbreviations: $b c=$ bacteriocyte; $b l=$ blood lacuna; $\mathrm{cc}=$ coelomic cavity; $\mathrm{dv}=$ dorsal blood vessel; $\mathrm{ep}=$ epidermis; od $=$ oviduct; iv $=$ intravasal body; $1 \mathrm{p}=$ lateral papilla; $\mathrm{ml}=$ body wall muscle layer; $\mathrm{ms}=$ mesenchyme; $\mathrm{py}=$ pyriform gland $; \mathrm{vv}=$ ventral blood vessel

Mesodermal structures and coelomic cavities

opisthosomal coelomic cavities (Fig. 7b). The long narrow glandular ducts extended along the septa through the muscle layer and the epidermis, and they opened to the exterior in a pore. Each multicellular glandular complex had a spacious lumen in the center. The glandular cells connected with apical junctional complexes and showed microvilli apically. The glandular cells contained a large lobed nucleus with a prominent nucleolus, extensive rER often arranged in concentric circles, mitochondria, Golgi complex, and electron-light granules containing electron-dark patches (Fig. 10a-c).
The body wall musculature was composed of an outer circular and an inner longitudinal muscle layer. These were prominent in the forepart and the trunk (Fig. 8d), but extremely thin in the opisthosoma (Fig. 10a). The few exceptions were the dorsal furrow in the anterior region and the tentacles, which exhibited only a single layer of longitudinal myoepithelial cells (Fig. 8a).

Each tentacle had a central coelom filled by mesenchymal cells at its base (Fig. 4a, b). These mesodermal strands connected to the solid mesoderm of the forepart, which was 


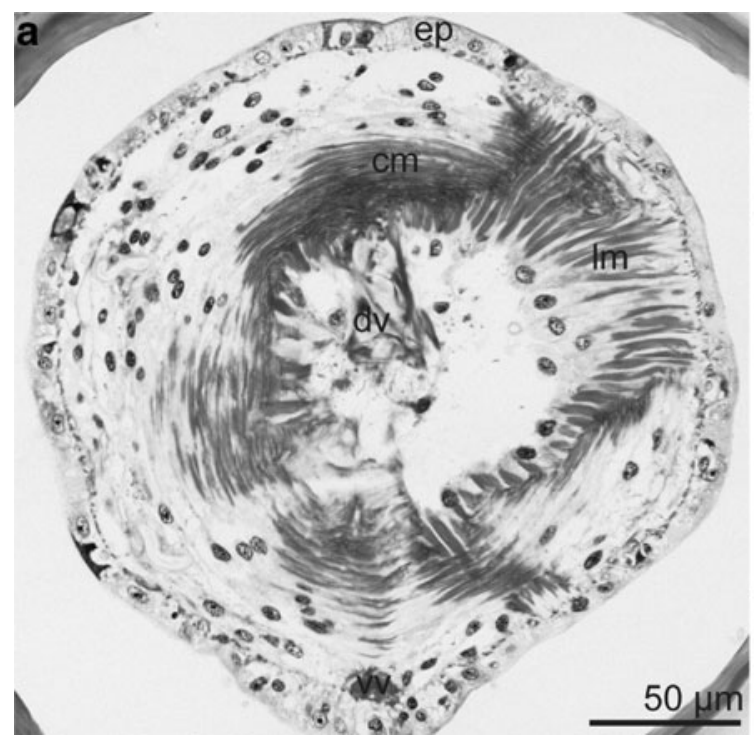

Fig. 7 Semithin section series of the opisthosoma. a Opisthosomal septum consisting of an anterior circular and a posterior longitudinal myoepithelial layer. b Multicellular epidermal glands with prominent nuclei (arrowhead) filling the coelomic cavity of the opisthosoma. Median mesentery (arrow) provided with blood lacunae and

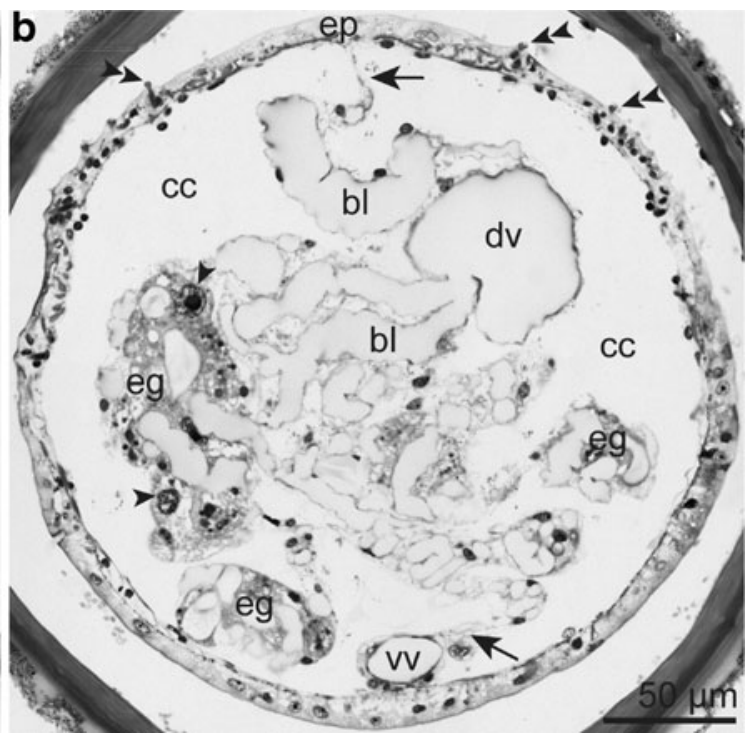

suspending the ventral and dorsal blood vessel. Last one at a more median position. Double arrowhead $=$ uncini. Abbreviations: $\mathrm{bl}=$ blood lacuna; $\mathrm{cc}=$ coelomic cavity; $\mathrm{cm}=$ circular muscle layer; $\mathrm{dv}=$ dorsal blood vessel; eg = epidermal gland; ep = epidermis; $1 \mathrm{~m}=$ longitudinal muscle layer; vv $=$ ventral blood vessel
Fig. 8 Ultrastructure of body wall layer and nervous system. a Body wall of tentacle composed of vascularized epidermis and a single layer of longitudinal muscle cells; in between the basal matrix (arrowhead). b Detail of ventral ciliated field of the forepart showing neuropil of one cord of the bifurcated ventral nerve and small nerves (arrow head) innervating the ciliated cells. c Ciliated cells forming part of the dorsal furrow of a male specimen. d Ventral nerve cord and body wall layer of the posterior trunk region. Abbreviations: $\mathrm{bc}=$ bacteriocyte; $\mathrm{bl}=$ blood lacuna; $\mathrm{cc}=$ coelomic cavity; $\mathrm{cf}=$ ciliated field; $\mathrm{cu}=$ cuticle; ep = epidermis; $\mathrm{mc}=$ myocyte; $\mathrm{ml}=$ body wall muscle layer; $\mathrm{mm}=$ median mesentery; $\mathrm{np}=$ neuropil; $\mathrm{vv}$ ventral blood vessel
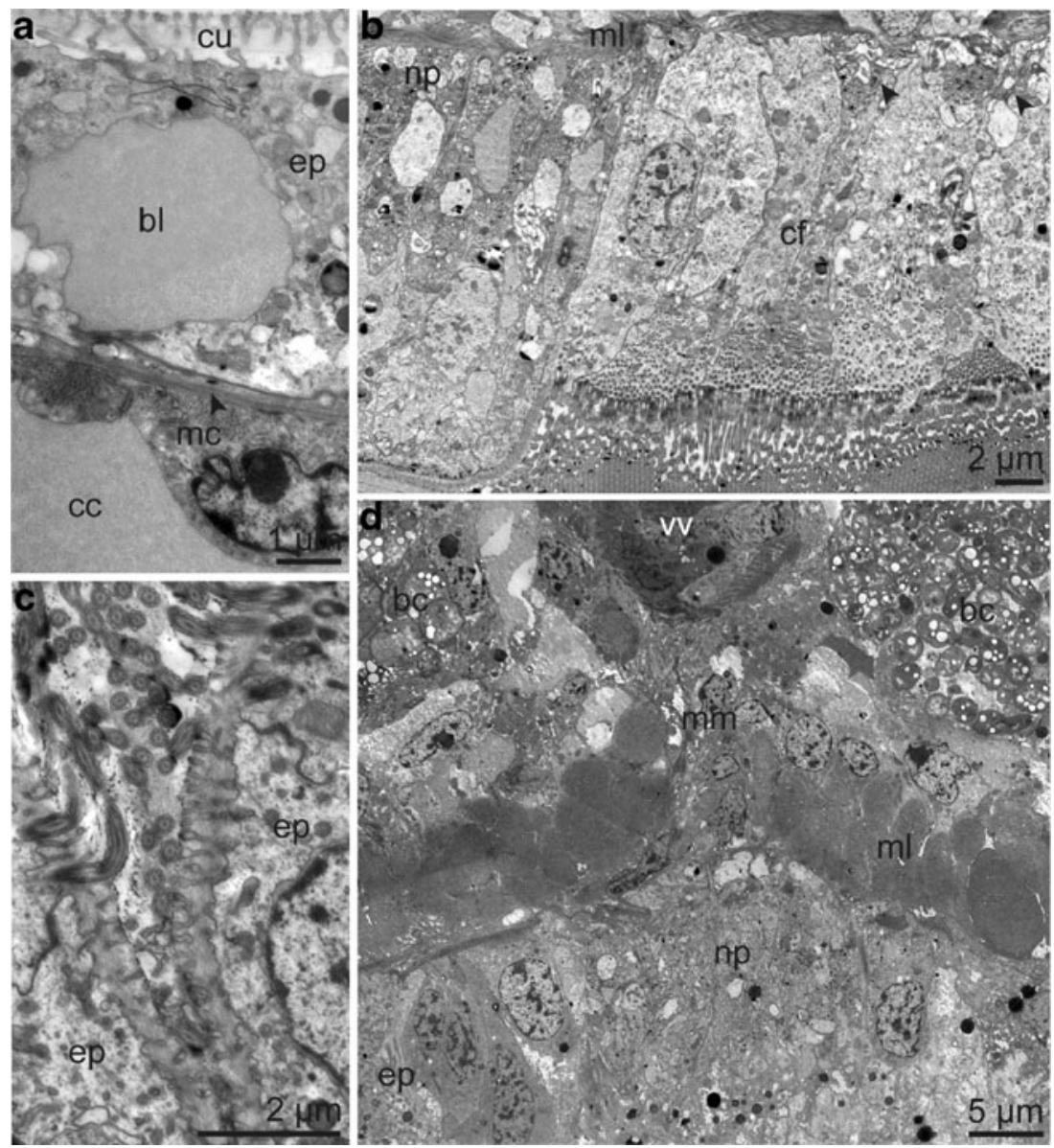

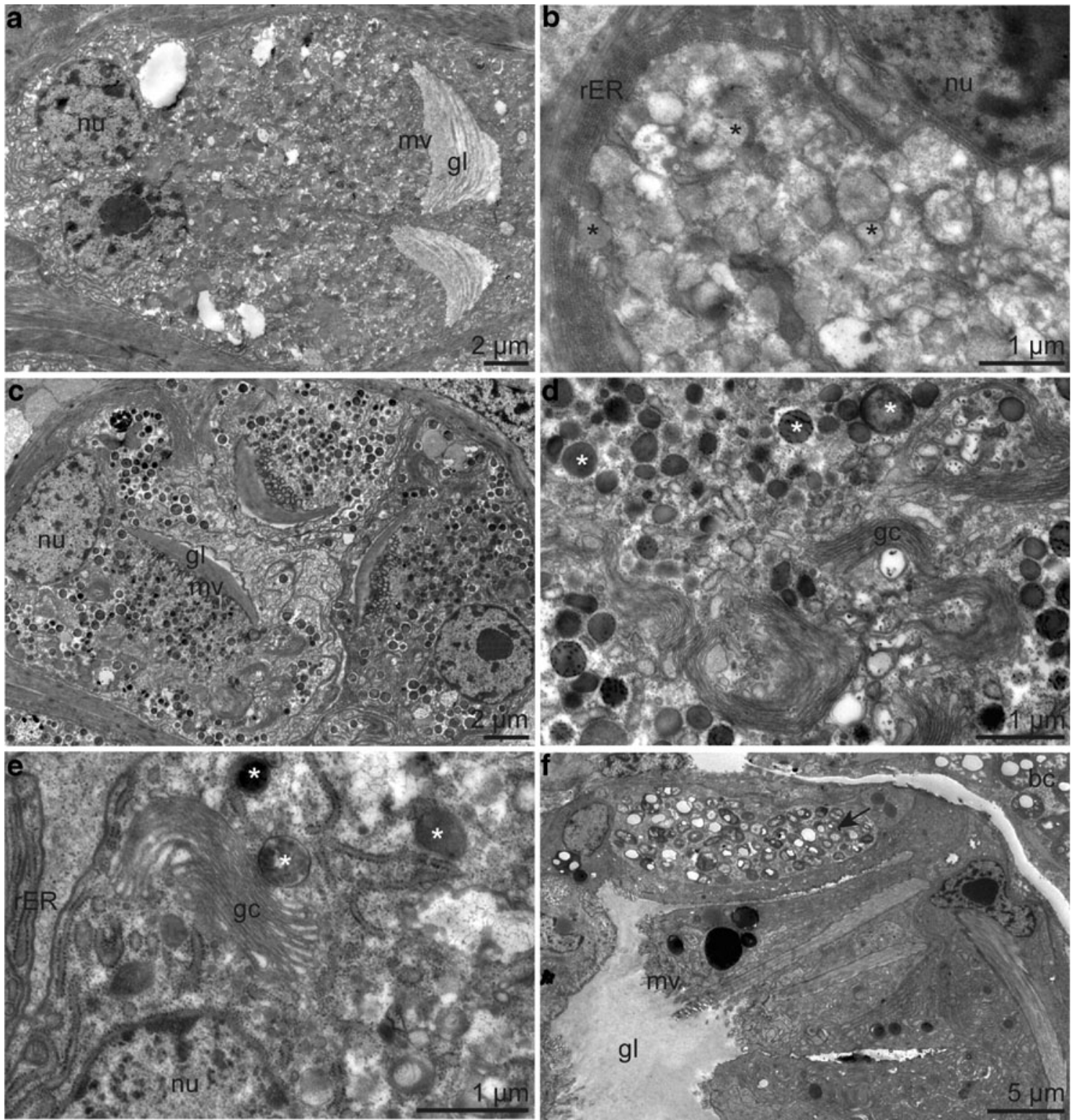

Fig. 9 Ultrastructure of pyriform glands of forepart a-e and trunk f. a Pyriform gland anterior to the frenulum $\mathbf{b}$ with cytoplasm containing amorphous secretion products (asterisk) and rER. c Pyriform gland posterior to the frenulum $\mathbf{d}$ with cytoplasm characterized by electrondark granules (asterisk) and Golgi complexes. e Detail of a pyriform

composed of mesenchymal cells rich in glycogen and interspersed with intercellular blood lacunae and muscle cells of different orientations. There was no visible coelomic cavity within the anterior region (Fig. 4c, d).

The trophosome - an organ of visceral mesodermal origin (Eichinger et al. 2011) —extended over the entire trunk. It was composed of a small bacteriocyte population and an extensive mesenchyme anteriorly (Fig. 6a, b), while posteriorly it consisted of a large bacteriocyte population and a peripheral peritoneum (Fig. 6c). Only glandular cell in the region of the ciliated field with granules (asterisk). f Pyriform gland of the trunk, one glandular cell containing intracellular bacteria (arrow). Abbreviations: $\mathrm{bc}=$ bacteriocyte; $\mathrm{gl}=$ glandular lumen; $\mathrm{gc}=$ Golgi comlex; $\mathrm{mv}=$ microvilli; $\mathrm{nu}=$ nucleus; $\mathrm{rER}=$ rough endoplasmic reticulum

some small spaces between the body wall muscle layer and the mesenchyme or peritoneum, respectively, represented the coelomic cavities.

The series of opisthosomal paired coelomic cavities was partitioned by septa. They were composed of two myoepithelial layers each that inserted into the body wall muscle layer through desmosomes. Circular muscles formed the anterior face, longitudinal muscles the posterior face (Fig. 7a). There were no blood lacunae within the basal matrices between the two muscle layers. 


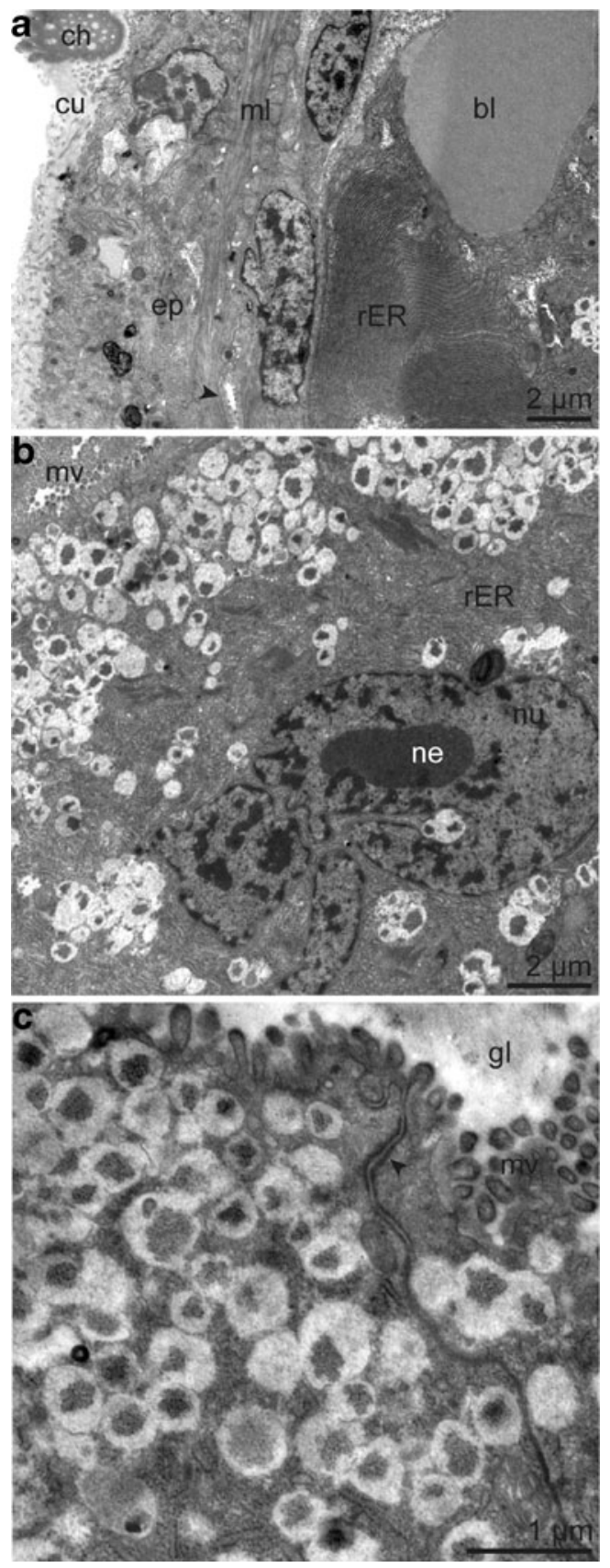

Fig. 10 Ultrastructure of epidermal multicellular glands of the opisthosoma. a Overview of epidermis, muscle layer with glandular duct (arrowhead) and glandular cell with rER in concentric circles, next to blood lacuna. b Glandular cell with large-lobed nucleus and nucleolus. c Detail of glandular epithelium showing apical junctional complex (arrowhead) and cytoplasm full of electron-light granules containing electron-dark patches. Abbreviations: $\mathrm{bl}=$ blood lacuna; $\mathrm{ch}=$ chaetae; $\mathrm{cu}=$ cuticle; $\mathrm{gl}=$ glandular lumen; $\mathrm{ml}=$ body wall muscle layer; $\mathrm{mv}=$ microvilli; ne $=$ nucleolus; $\mathrm{nu}=$ nucleus; $\mathrm{rER}=$ rough endoplasmic reticulum

\section{Vascular system}

The vascular system consisted of the dorsal and ventral blood vessels, the blood vessels of the tentacles, the blood vessels of the ovary, and a network of intercellular blood lacunae.

Each tentacle had two opposing blood vessels located within the basal matrices between a highly vascularized epidermis and longitudinal myoepithelial cells. Blood lacunae between the epidermis and the muscle layer, and between the epidermal cells, connected the two blood vessels with each other (Figs. 4a, 8a). More proximally the vessels lay between the epidermis and a mesenchyme (Fig. 4a), and at the base of the tentacles the vessels could not be traced.

The lining of the ventral and the dorsal blood vessels was the median mesentery composed of myoepithelial cells except for the dorsal vessel of the trunk region where some bacteriocytes contributed to this epithelium (Eichinger et al. 2011). The two longitudinal blood vessels opened at regular intervals and connected with a network of intercellular blood lacunae located within the mesoderm of the forepart (Fig. 4d), between the mesenchymal cells and/or the bacteriocytes of the trunk region (Fig. 6b), and within the median mesentery of the opisthosoma (Fig. 7b). The dorsal blood vessel was paired at its anterior end (Fig. 4c), most probably representing the branches of the afferent vessels of the tentacles. At the anterior margin of the trunk, within the region of the genital openings, prominent muscles encircled the dorsal vessel (Fig. 5a, b). Within the opisthosoma, the dorsal blood vessel ran at a more central position (Fig. 7b).

A distinct cell cord on the ventral side in the dorsal blood vessel formed an intravasal body sensu Schulze (2002) over the whole length of the body except the opisthosoma. It thickened several times within the trunk, blocking the dorsal blood vessel (Fig. 6a).

\section{Female reproductive system}

A single ovary was located ventrally on the right side of the ventral blood vessel and started approximately after one third of the trunk. At its posterior end it bent, forming a lateral pouch, and passed anteriorly as an oviduct running parallel to the ovary (Fig. 11a). The oviduct opened dorsally posterior to the dorsal furrow, slightly anterior to the end of the ventral ciliated field (Fig. 5a). The wall of the oviduct consisted of a ciliated epithelium with apical junctional complexes and a basal matrix surrounded by a thin myoepithelium (Fig. 11b).

Within the ovary the stacked developing eggs increased in size from anterior to posterior. Oocytes of the posterior ovary had a large germinal vesicle containing a prominent nucleolus and were packed with yolk granules and lipid droplets, indicating that they were in the vitellogenetic phase of the first meiotic prophase. Oocytes were surrounded by flattened follicle cells as well as by blood vessels (Fig. 11c). Blood lacunae were in direct contact with the oocytes, even forming small branches ramifying into the 
Fig. 11 Female reproductive system. a Semithin transverse section of the single ovary provided with small blood vessels (asterisk), containing oocytes, located between the oviduct and the ventral blood vessel. b Ultrastructure of the oviduct composed of an inner ciliated epithelium with apical junctional complexes

(arrowhead) and a basal matrix (double arrowhead) surrounded by a myoepithelium. c Oocyte in the first meiotic prophase full of yolk granules and lipid droplets surrounded by a small blood vessel, blood lacuna and flattened follicle cells. d Oocyte in direct contact with blood lacuna ramifying into the oolemma (arrowhead). e Egg envelope consisting of extracellular matrix penetrated by microvilli. f Light microscopy of oocyte. Abbreviations: $\mathrm{bc}=$ bacteriocyte; $\mathrm{bl}=$ blood lacuna; $\mathrm{bv}=$ blood vessel; $\mathrm{cc}=$ coelomic cavity; $\mathrm{ci}=$ cilium; ep = epidermis; $\mathrm{fc}=$ follicle cell; ge $=$ germinal vesicle; $1 \mathrm{~d}=$ lipid droplet; $\mathrm{mc}=$ myocytes; $\mathrm{ml}=$ body wall muscle layer; $\mathrm{mm}=$ median mesentery; $\mathrm{ms}=$ mesenchyme; $\mathrm{mv}=$ microvilli; $\mathrm{ne}=$ nucleolus; oc $=$ oocyte; od $=$ oviduct; vv = ventral blood vessel; $\mathrm{y}=$ yolk granule
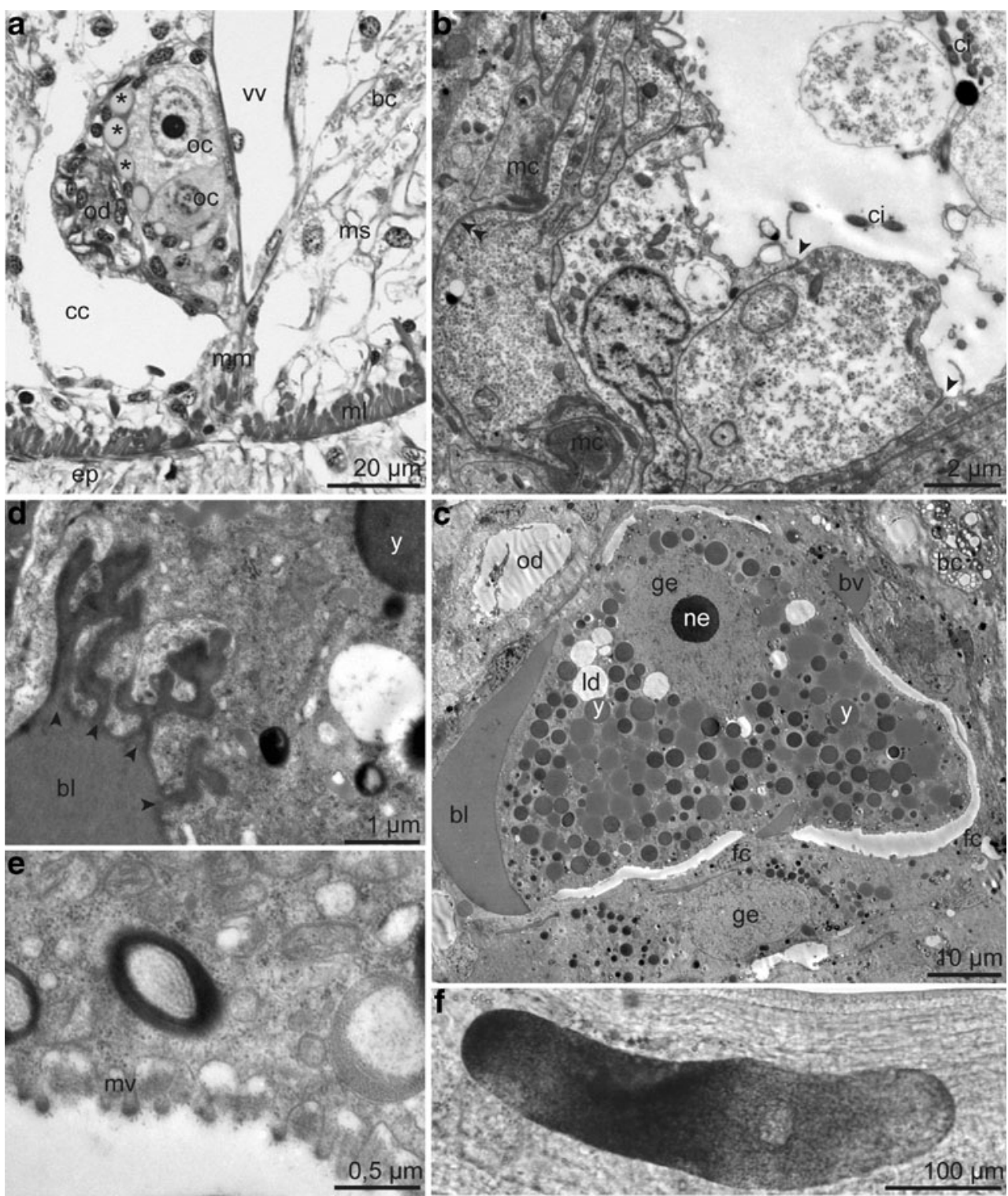

oocytes (Fig. 11d). The egg envelope was formed of an extracellular matrix penetrated by oocyte microvilli in regions where the follicle cells were lifted off the oolemma (Fig. 11e). Oval-shaped eggs detected within the anterior oviduct were up to $430 \mu \mathrm{m}$ in length and $110 \mu \mathrm{m}$ in diameter (Fig. 11f). We did not detect any sperm in the female reproductive system.

\section{Male reproductive system}

In the male specimen, parts of the epidermis of the posterior dorsal furrow were ciliated (Fig. 8c). The furrow broadened at its end, forming two ciliated dorsal grooves extending to two genital papillae located dorsally, slightly posterior to the end of the ventral ciliated field (Fig. 5b). These papillae were the openings of paired sperm ducts full of conspicuous filiform spermatozoa. The sperm ducts were connected to the ventral mesentery on either side of the ventral blood vessel (Fig. 12a) and consisted of two opposite-orientated epithelia (Fig. 12b).

The spermatozoa were composed of a helical acrosome, an elongated coiled nucleus surrounded by helical mitochondria, a short centriolar region, and a long flagellum with a $9 \times 2+2$ pattern (Fig. $12 \mathrm{c}-\mathrm{f}$ ). Neither spermatophores nor spermatozeugmata could be detected.

\section{Discussion}

Biogeography of Sclerolinum contortum and intraspecific morphological plasticity

The molecular phylogeny of the Siboglinidae based on the mitochondrial $16 \mathrm{~S}$ is in agreement with the phylogeny based on this genetic marker and the nuclear $18 \mathrm{~S}$ marker (Rouse et 


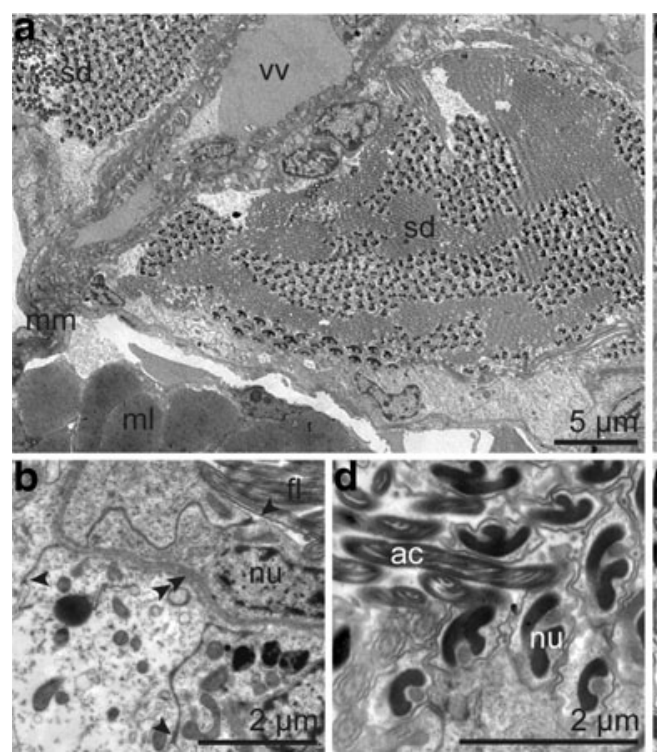

Fig. 12 Ultrastructure of the male reproductive system. a Sperm ducts left and right of the ventral blood vessel packed with sperm. b Epithelium of the sperm duct with apical junctional complexes (arrowhead) surrounded by the coelomic lining (left side); in between the basal matrix (double arrowhead). c Longitudinal section through spermatozoa. d Longitudinal section through the thread-like acrosome attached

al. 2004): Sclerolinum is sister to vestimentiferans, Osedax is sister to this group, and frenulates are sister to all three. There is little to no difference in sequences of Sclerolinum GoM and the Northeastern Atlantic specimens of S. contortum. Although mitochondrial markers have been shown to have a limited resolution in the cold-seep vestimentiferan genera Lamellibrachia and Escarpia (Andersen et al. 2004; Miglietta et al. 2010), the lack of differences likely indicates that $S$. contortum has a wide geographic distribution, from the Gulf of Mexico to the Arctic Sea (Lazar et al. 2010; Lösekann et al. 2008; Pedersen et al. 2010; Smirnov 2000).

The most conspicuous character of $S$. contortum is its tube, which is anteriorly highly meandering and posteriorly more or less straight. Additionally, this species is characterized by a dense arrangement of the frenular plaques. The measured specimens from the GoM are larger than the ones from the arctic HMMV. Nevertheless, regardless of the worm's size, several morphological characters, such as the number and size of frenular plaques, the numbers of opisthosomal segments, and the length of opisthosoma, differ between the two populations (Table 1). In the absence of molecular data, one could have classified the two populations as separate species. Sequence data of more Sclerolinum species from various populations would be useful to improve our knowledge on the intraand interspecific morphological variability and biogeography of this small genus inhabiting diverse reducing environments all over the world.

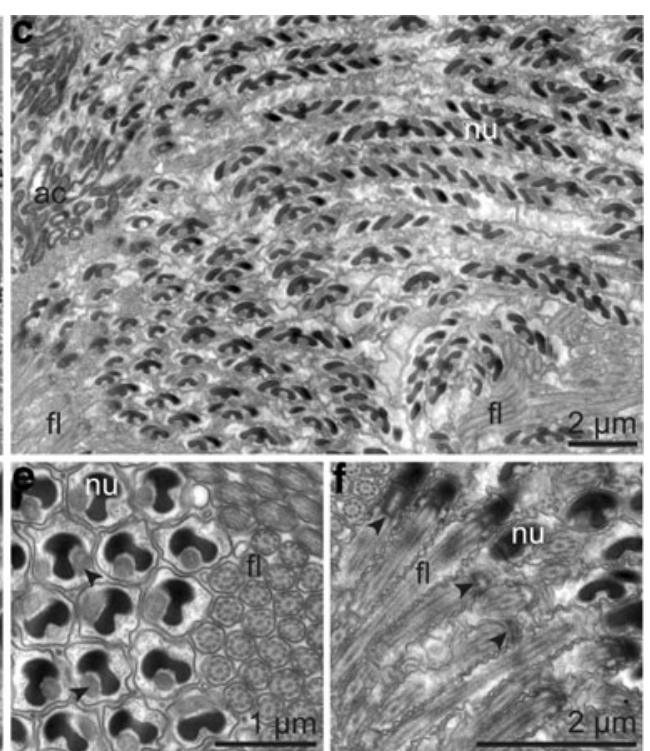

to the head region. e Transversal section through the nuclear grooves occupied by mitochondria (arrowhead) and the cilia. f Longitudinal section through the basal region of the nucleus, the centriolar region (arrowhead), and flagellum. Abbreviations: $\mathrm{ac}=$ acrosome; $\mathrm{fl}=$ flagellum; $\mathrm{ml}=$ body wall muscle layer; $\mathrm{mm}=$ median mesentery; $\mathrm{sd}=$ sperm duct; $\mathrm{nu}=$ nucleus; $\mathrm{vv}=$ ventral blood vessel

Sclerolinum body organization in comparison with vestimentiferan and frenulate body organization

Studying the adult morphology and microanatomy of Sclerolinum contortum GoM and comparing it with the closely related vestimentiferans and the more distantly related frenulates, we propose a hypothesis on the Sclerolinum adult body regions as follows: (1) The forepart plus the cephalic lobe, containing the brain, is homologous to the vestimentum of vestimentiferans. (2) The trunk is homologous to the trunk of vestimentiferans and includes the reproductive system and the trophosome. (3) The opisthosoma is homologous to the opisthosoma of vestimentiferans and frenulates (Fig. 13).

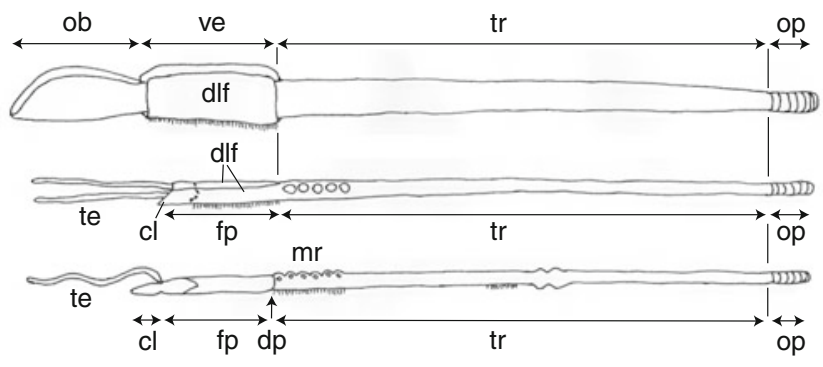

Fig. 13 Schematic drawing modified from Southward et al. (2005) comparing the different body regions of a vestimentiferans, b Sclerolinum, and $\mathbf{c}$ frenulates. Abbreviations: $\mathrm{cl}=$ cephalic lobe; $\mathrm{dlf}=$ dorsolateral folds; $\mathrm{dp}=$ diaphragm; $\mathrm{fp}=$ forepart $\mathrm{mr}=$ metameric region; $\mathrm{ob}=$ obturaculum; $\mathrm{op}=$ opisthosoma; te $=$ tentacle; $\operatorname{tr}=$ trunk; $\mathrm{ve}=$ vestimentum 
(1) Several studies homologized the forepart of Sclerolinum with both the frenulate forepart and the vestimentiferan vestimentum (Hilário et al. 2011; Rouse 2001; Rouse and Pleijel 2001; Rousset et al. 2004; Southward et al. 2005; Webb and Ganga 1980). In contrast to this, we propose that the Sclerolinum forepart, extending from the tip of the cephalic lobe to the end of the dorsal furrow, corresponds to the vestimentiferan vestimentum, but we do not consider the Sclerolinum forepart as homologous to the frenulate forepart. This is supported by cross sections of the forepart of $S$. contortum GoM revealing striking similarities with the vestimentiferan vestimentum. Both taxa exhibit dorsolateral folds either forming the narrow, dorsal furrow in Sclerolinum or the more extended vestimental wings of vestimentiferans. In both cases, the epidermis as well as the somatic musculature contributes to the dorsal interfolding. A ventral ciliated field bordered by a nerve cord is restricted to the forepart or vestimentum. The glandular arrangements in these body regions are very similar in both taxa. In $S$. contortum GoM the pyriform glands are densely arranged across the forepart and never open into the dorsal furrow. In vestimentiferans the glands are distributed from the nerve cord to the edges of the vestimental wings (Gardiner and Jones 1993; Malakhov et al. 1996c, b; Webb and Ganga 1980). Finally, in neither Sclerolinum nor vestimentiferans does a diaphragm separating this anterior body region from the trunk exist (Nussbaumer et al. 2006).

In comparison, in frenulates, a dorsal furrow is mentioned in several frenulate species (Hilário and Cunha 2008; Ivanov 1963; Southward 1961, 1972; Southward 1991). However, this furrow is only a small interfolding of the epidermis alone (Ivanov 1963) and does not involve the somatic musculature as in Sclerolinum and vestimentiferans. The frenulate forepart is free of a ventral ciliated region. During development only the posterior part of the neurotroch present in the metatrochophore remains as ventral ciliated field of the anterior trunk in adult frenulates (Callsen-Cencic and Flügel 1995). The glandular arrangement of the frenulate forepart is variable between species, while it is similar in $S$. contortum GoM and vestimentiferans. Glands seem to be restricted to the region posterior to the frenulum in frenulates. They are arranged throughout the whole region in Lamellisabella zachsi (Ivanov 1963), as two separated patches in Oligobrachia ivanovi (Southward 1959), or confined to one patch just behind the frenulum in Siboglinum caulleryi (Ivanov 1963). A diaphragm formed during development and persisting into the adult frenulate (Ivanov 1963; Southward 1993) delineates the end of the forepart. Such a structure is absent in adults of Sclerolinum and juvenile vestimentiferans (Nussbaumer et al. 2006).

In vestimentiferans the vestimentum arises from the prostomium, peristomium, and the anterior part of the first chaetiger during larval development (Nussbaumer et al.
2006), and the vestimentum is interpreted as the worm's head (Bright et al. 2012). Although the developmental fate of the prostomium and the peristomium in Sclerolinum are unknown and only developmental studies will ultimately provide evidence, we suggest that in Sclerolinum the head is composed of the cephalic lobe (most likely the prostomium) and the forepart (interpreted as the peristomium and the anterior part of the first chaetiger) and that it is homologous to the vestimentiferan head. The tentacles are considered head appendages.

All siboglinids exhibit tentacles; in vestimentiferans and frenulates they are of different origin. In vestimentiferans, tentacles and the obturacular region are differentiations of the first chaetiger (Nussbaumer et al. 2006). In contrast, detailed drawings of Ivanov (1975) as well as the schematic drawing of Webb (1964a) clearly show that in the frenulate metatrochophore the coelom of the tentacles originates from the anterior most coelom (protocoel sensu Ivanov), which is located anterior to the paired coelom of the first chaetiger. We interpreted the Sclerolinum tentacles as anterior differentiations of the first chaetiger, and consequently they are hypothesized to have a similar origin to those of vestimentiferans. Support comes from the adult organization of the mesoderm, which is continuous between the tentacles and the forepart.

In Sclerolinum the brain is located at the base of the cephalic lobe, a miniscule epidermal extension of the forepart, and extends into the anteriormost region of the forepart. The brain of vestimentiferans and frenulates develops in the prostomium of the metatrochophore (Ivanov 1963; Nussbaumer et al. 2006; Southward 1993). In vestimentiferans, the prostomium and the peristomium merge with the anteriormost part of the first chaetiger during development, forming the vestimentum (Nussbaumer et al. 2006), so that the brain is located at the anterior margin of the vestimentum in adults. In contrast, in the frenulates the prostomium persists as a prominent cephalic lobe in adults, and the brain is located within the cephalic lobe and the anterior forepart (Ivanov 1963; Southward 1993). Therefore we hypothesize that the cephalic lobe gradually reduced during siboglinid evolution, leading to an incorporation into the vestimentiferan head and consequently to an inclusion of the brain into the anteriormost part of the vestimentum.

The frenulum of Sclerolinum is variable. In most species, a row of plaques, sometimes partially fused (Southward 1961; Webb 1964b), is developed. Only in S. major are scattered plaques limited to a small region reported (Southward 1972). In S. contortum GoM, however, we detected an intraspecific variation in the arrangement of the plaques, either in a row as in most other Sclerolinum species or in a more scattered distribution more similar to vestimentiferans. In the latter situation, plaques are distributed randomly along the outer surface of the vestimentum 
(Gardiner and Jones 1993; Southward 1991). The frenulate frenulum is a pair of cuticular crests, which develops from cuticular plaques in Nereilinum murmanicum (Ivanov 1975). Interestingly, the frenula of some species such as Unibrachium colombianum (Southward 1972) or Siboglinum meridiale (Ivanov 1963) look like a Sclerolinum frenulum.

The excretory organs are located in the anterior frenulate forepart and vestimentiferan vestimentum (Gardiner and Jones 1993; Ivanov 1963). In spite of careful investigations, we could not locate an excretory system in Sclerolinum.

(2) Lacking a diaphragm between the forepart and the trunk, we define the beginning of the Sclerolinum trunk (interpreted as the posterior part of the first chaetiger) internally with the beginning of paired trunk coelomic cavities, the reproductive system, and the trophosome and externally by the gonopores. This also corresponds to the organization of vestimentiferans (Webb and Ganga 1980).

The trunk of $S$. contortum GoM, starting at the level of the gonopores and terminating with the first opisthosomal septum, is homologous to the vestimentiferan trunk, which develops from the posterior part of the first chaetiger (Nussbaumer et al. 2006). Evidence comes from comparative adult morphology. Vestimentiferans and Sclerolinum have a trunk lacking a ventrally ciliated region, but covered irregularly by small plaque-bearing papillae (Gardiner and Jones 1993; Malakhov et al. 1996b; Webb and Ganga 1980). Sclerolinum has girdles of uncini at the end of the trunk (Southward 1972). These might correspond to chaetae found in juvenile vestimentiferans (Jones and Gardiner 1989; Southward 1988; Southward et al. 2011) but are lost in adults. The trophosome in Sclerolinum and vestimentiferans extends over the whole length of the trunk and originates from the visceral mesoderm (Bright and Sorgo 2003; Eichinger et al. 2011).

In contrast, the frenulate trunk is anteriorly ciliated [originating at the posterior part of the neurotroch according to Callsen-Cencic and Flügel (1995)], exhibits papillae restricted to specialized regions, and girdles at the mid-trunk position (Ivanov 1963; Webb and Ganga 1980). The trophosome is restricted to the posterior two thirds of the trunk and develops from the endoderm of the gut (Callsen-Cencic and Flügel 1995; Southward 1993).

The metameric trunk region of frenulates is characterized by two rows of large papillae containing pyriform glands. According to Ivanov (1963), these papillae are bulges of the epidermis that are separated from the general body cavity by a basement membrane and musculature. The glands are confined to these papillae. In contrast, in vestimentiferans small epidermal elevations, called papillae as well, cover the trunk irregularly. These papillae are the openings of pyriform glands as well; however, they extend deeply between the muscular tissues (Malakhov et al. 1996b; van der Land and Norrevang
1977). Our investigations clearly revealed that the two lateral rows of epidermal papillae restricted to the anterior trunk of $S$. contortum GoM are simple epidermal elevations as described for vestimentiferans. They are the openings of pyriform glands extending deeply into the body cavity.

Due to these structural differences, we do not consider the anterior trunk region of Sclerolinum as homologous to the metameric region of frenulates. This is in consensus with Rouse (2001) and Rouse and Pleijel (2001). On the contrary, Schulze stated that the metameric region was the only synapomorphy for frenulates and Sclerolinum and placed Sclerolinum as sister to frenulates. Also, the combined molecular and morphological analysis of Rousset et al. (2004) scored the metameric region as present in Sclerolinum, and the tree based on morphological data only shows Sclerolinum as sister to a clade formed by vestimentiferans and frenulates.

The Sclerolinum body lacks any internal partition except for the opisthosomal septa. Instead, there are some massive thickenings of the epidermis and longitudinal muscle layer in combination with highly abundant cuticular plaques in the posterior trunk region, which most probably serve locomotion. Ivanov and Selivanova (1992) may have erroneously referred to such a constriction of the body cavity by describing a septum behind a very long forepart (referred to as the mesosoma) of S. javanicum.

(3) Despite some peculiarities, the opisthosoma of Sclerolinum contortum GoM is homologous to the vestimentiferan and frenulate opisthosoma. It has a median mesentery, present in vestimentiferans, but missing in adult frenulates (Southward 1975). The opisthosomal septa of $S$. contortum GoM are composed of two myoepithelial layers as described for the vestimentiferan metatrochophore (Bright et al. 2012) and the adult vestimentiferan Riftia pachyptila (Jones 1981). The vestimentiferan Ridgea piscesae (Southward et al. 2005) and the frenulate Siboglinum fiordicum (Southward 1975) have only the posterior epithelia of the septa muscular.

We found one type of multicellular gland in the opisthosoma of S. contortum GoM. These glands are connected to the blood vascular system and resemble the typical pyriform glands of Siboglinidae neither structurally nor cytologically. The adult vestimentiferan $R$. pachyptila has two kinds of multicellular opisthosomal glands: one described as short and broad, the other one as long and slender. Both differ histologically from the pyriform glands of the rest of the body, but only the long and slender type is associated with blood vessels (Jones 1980). In R. piscesae peripheral pyriform glands are distinguished from central glands surrounded by blood lacunae (Southward et al. 2005). Frenulates lack multicellular glands in the opisthosoma (Southward 1975). 
The opisthosomal blood vascular system of Sclerolinum consisting of one ventral and one dorsal vessel linked by blood lacunae located within the median mesentery is unique within Siboglinidae since in the vestimentiferan Riftia pachyptila as well as in the frenulate Siboglinum fiordicum the longitudinal blood vessels communicate through septal vessels within the opisthosoma only (Gardiner and Jones 1993; Southward 1975).

Another unique characteristic of the Sclerolinum opisthosoma is a broad ventral nerve field. One single nerve cord is described from the vestimentiferan opisthosoma (Jones 1980; Malakhov et al. 1996b) and three separated nerve cords from the opisthosoma of the frenulate S. fiordicum (Southward 1975).

Reproductive systems and reproduction

In Sclerolinum contortum GoM as well as in vestimentiferans the sex can be differentiated externally by the presence of ciliated grooves extending anteriorly from the male gonopores (Gardiner and Jones 1993; Webb 1977). The filiform mature spermatozoa of Sclerolinum are of the modified sperm type sensu Franzén (1956) and the ent-aquasperm type sensu Rouse and Jamieson (1987), and they correspond with the sperm morphology found in other Siboglinidae, including Osedax species. In all four siboglinid taxa, mature sperm are elongated cells with a helical acrosome, a helical nucleus wrapped by mitochondria, and a long flagellum (Franzén 1973; Gardiner and Jones 1985; Katz unpubl. $\mathrm{PhD}$ thesis). The spermatozoa of Sclerolinum lie unpackaged within the sperm ducts. Free sperm is also reported from Osedax (Katz unpublished $\mathrm{PhD}$ thesis), whereas in frenulates sperm is bundled into spermatophores and in vestimentiferans into spermatozeugmata (Ivanov 1963; Jones and Gardiner 1985).

Only the right side of the female reproductive system exists in S. contortum GoM, forming a U-shaped system. A bent female reproductive system is the norm in vestimentiferans and frenulates (Hilário et al. 2005; Ivanov 1963; Webb 1977). An asymmetry of the female reproductive system with one side much shorter than the other is reported from the vestimentiferans Lamellibrachia barhami (Webb 1977), Tevnia jerichonana (Gardiner and Jones 1993), and Ridgeia piscesae (Malakhov et al. 1996a), but not in Riftia pachyptila (Gardiner and Jones 1993). No asymmetry is mentioned from frenulate females. On the other hand, females of Osedax have one long gonoduct running along the trunk, possibly leading to a single ovary filling the ovisac (Rouse et al. 2004, 2008).

As far as is known, fertilization is internal in frenulates (Southward 1999), Osedax (Rouse et al. 2009, 2008), and vestimentiferans (Hilário et al. 2005). Female vestimentiferans have a region of sperm storage at the posterior end of the oviducts, and zygotes are released as primary oocytes (Hilário et al. 2005). Although we could not detect sperm within the pouch of the oviduct by light microscopy, it probably represents a spermatheca. This would point to an internal insemination in Sclerolinum as well. Nevertheless, investigations on sperm uptake, fertilization, and larval development of Sclerolinum are urgently needed.

\section{Conclusion}

To date, Sclerolinum species have been described exclusively by the external morphology. This study provides, for the first time, a detailed description of the internal adult anatomy of a Sclerolinum species, confirming the close relationship between the sister taxa Sclerolinum and vestimentiferans. The Sclerolinum forepart, including the miniscule cephalic lobe, corresponds in its organization to the vestimentiferan vestimentum. We suggest referring to this region as the head. The Sclerolinum trunk corresponds to the vestimentiferan trunk. There is no diaphragm separating the head from the trunk. Future attempts to find Sclerolinum larvae would be useful to trace the fate of the prostomium, peristomium, tentacular coeloms, and the coelom of the first chaetiger to elucidate the developmental origin of the Sclerolinum body regions.

Acknowledgments We would like to thank C.R. Fisher for inviting us to the cruise "Expedition to the Deep Slope," the captain and crew of the NOAA Ship Ron Brown, and the crew of the ROV Jason for their expertise and assistance. Special thanks go to D. Gruber and G. Spitzer (Core Facility for Cell Imaging and Ultrastructure Research) for their helpful support. The production of the semithin section series by $\mathrm{T}$. Schwaha is highly acknowledged. This study was financially supported by the Austrian Science Foundation P20282-B17 and the Initiativkolleg 'Symbiotic Interactions' of the University of Vienna. Northeast Atlantic specimens of Sclerolinum contortum were kindly provided by A. Andersen. They were collected during a program supported by the HERMES project, EC contract no. GOCE-CT-2005-511234, funded by the European Commission's Sixth Framework Program under the priority 'Sustainable Development, Global Change and Ecosystems.' The phylogeny work was achieved with the support of the European Community Seventh Framework Programme (FP7/2007-2014) under the HERMIONE project (Hotspot Ecosystem Research and Man's Impact on European Seas), grant agreement no. 226354.

Open Access This article is distributed under the terms of the Creative Commons Attribution License which permits any use, distribution, and reproduction in any medium, provided the original author(s) and the source are credited.

\section{References}

Andersen, A. C., Hourdez, S., Marie, B., Jollivet, D., Lallier, F. H., \& Sibuet, M. (2004). Escarpia southwardae sp. nov., a new species of vestimentiferan tubeworm (Annelida, Siboglinidae) from West African cold seeps. Canadian Journal of Zoology, 82, 980-999. 
Bakke, T. (1977). Development of Siboglinum fiordicum Webb (Pogonophora) after metamorphosis. Sarsia, 63, 65-73.

Bright, M., \& Sorgo, A. (2003). Ultrastructural reinvestigation of the trophosome in adults of Riftia pachyptila (Siboglinidae, Annelida). Invertebrate Biology, 122, 345-366.

Bright, M., Eichinger, I., \& Salvini-Plawen, L. (2012). The metatrochophore of a deep-sea hydrothermal vent vestimentiferan (Polychaeta: Siboglinidae). Organisms Diversity and Evolution, in review

Callsen-Cencic, P., \& Flügel, H. J. (1995). Larval development an the formation of the gut of Siboglinum poseidoni Flügel \& Langhof (Pogonophora, Perviata). Evidence of protostomian affinity. Sarsia, 80, 73-89.

Doyle, J. J., \& Doyle, J. L. (1987). A rapid DNA isolation procedure for small quantities of fresh leaf tissue. Biological Sciences, 19(1), 11-15.

Eichinger, I., Klepal, W., Schmid, M., \& Bright, M. (2011). Organization and microanatomy of the Sclerolinum contortum trophosome (Polychaeta, Siboglinidae). The Biological Bulletin, 220(2), 140-153.

Felbeck, H. (1981). Chemoautotrophic potential of the hydrothermal vent tube worm, Riftia pachyptila Jones (Vestimentifera). Science (Washington), 213, 336-338.

Felbeck, H., Childress, J. J., \& Somero, G. N. (1981). Calvin-Benson cycle and sulphide oxidation enzymes in animals from sulphiderich habitats. Nature, 293(5830), 291-293.

Franzén, A. (1956). On spermiogenesis, morphology of the spermatozoon and biology of fertilization among invertebrates. Zoologiska Bidrag från Uppsala, 31, 355-482.

Franzén, A. (1973). The Sparmatozoon of Siboglinum (Pogonophora). Acta Zoologica, 54, 179-192.

Gardiner, S. L., \& Jones, M. L. (1985). Ultrastructure of spermiogenesis in the vestimentiferan tube worm Riftia pachyptila (Pogonophora: Obturata). Transactions of the American Microscopical Society, 104(1), 19-44.

Gardiner, S. L., \& Jones, M. L. (1993). Vestimentifera. In F. W. Harrison \& M. E. Rice (Eds.), Microscopic anatomy of invertebrates 12, Onychophora, Chilopoda and Lesser Protostomata (pp. 371-460). New York: Wiley-Liss.

Goffredi, S. K., Orphan, V. J., Rouse, G. W., Jahnke, L., Embaye, T., Turk, K., et al. (2005). Evolutionary innovation: a bone-eating marine symbiosis. Environmental Microbiology, 7(9), 1369-1378.

Goffredi, S. K., Johnson, S. B., \& Vrijenhoek, R. C. (2007). Genetic diversity and potential function of microbial symbionts associated with newly discovered species of Osedax polychaete worms. Applied and Environmental Microbiology, 73(7), 2314-2323.

Halanych, K. M., Feldman, R. A., \& Vrijenhoek, R. C. (2001). Molecular evidence that Sclerolinum brattstromi is closely related to vestimentiferans, not to frenulate pogonophorans (Siboglinidae, Annelida). The Biological Bulletin, 201, 65-75.

Hilário, A., \& Cunha, M. R. (2008). On some frenulate species (Annelida: Polychaeta: Siboglinidae) from mud vulcanoes in the Gulf of Cadiz (NE Atlantic). Scientia Marina, 72(2), 361-371.

Hilário, A., Young, C. M., \& Tyler, P. A. (2005). Sperm storage, internal fertilization, and embryonic dispersal in vent and seep tubeworms (Polychaeta: Siboglinidae: Vestimentifera). The Biological Bulletin, 208, 20-28.

Hilário, A., Capa, M., Dahlgren, T. G., Halanych, K. M., Little, C. T. S., Thornhill, D. J., et al. (2011). New perspectives on the ecology and evolution of siboglinid tubeworms. PLoS One, 6(2), e16309.

Ivanov, A. V. (1963). Pogonophora. London: Academic Press.

Ivanov, A. V. (1975). Embryonalentwicklung der Pogonophora und ihre systematische Stellung. In A. Nørrevang (Ed.), The Phylogeny and Systematik Position of Pogonophora (pp. 10 44). Paul Parey, Zoological Central Institute, University of Copenhagen.
Ivanov, A. V. (1991). Monilifera-a new subclass of Pogonophora. Doklady Akademii Nauk SSSR, 319, 505-507.

Ivanov, A. V. (1994). On the systematic position of vestimentifera. Zoologische Jahrbucher - Abteilung für Anatomie und Ontogenie der Tiere, 121, 409-456.

Ivanov, A. V., \& Selivanova, R. V. (1992). Sclerolinum javanicum sp.n., a new pogonophoran living on rotten wood. A contribution to the classification of Pogonophora. Biologiya Morya (Vladivostok), 1-2, 27-33.

Jones, M. L. (1980). Riftia pachyptila, new genus, new species, the vestimentiferan worm from the Galápagos Rift geothermal vents (Pogonophora). Proceedings of the Biological Society of Washington, 93, 1295-1313.

Jones, M. L. (1981). Riftia pachyptila Jones: observations on the vestimentiferan worm from the Galápagos Rift. Science (Washington), 213(4505), 333-336.

Jones, M. L., \& Gardiner, S. L. (1985). Light and scanning electron microscopic studies of spermatogenesis in the vestimentiferan tube worm Riftia pachyptila (Pogonophora: Obturata). Transactions of the American Microscopical Society, 104(1), 1-18.

Jones, M. L., \& Gardiner, S. L. (1989). On the early development of the vestimentiferan tube worm Ridgeia sp. and observations on the nervous system and trophosome of Ridgeia sp. and Riftia pachyptila. The Biological Bulletin, 177, 254-276.

Katz, S. (2009). Osedax symbiosis - trophosome organization and aspects of fertilization. $\mathrm{PhD}$ thesis

Lazar, C., Dinasquet, J., Pignet, P., Prieur, D., \& Toffin, L. (2010). Active archaeal communities at cold seep sediments populated by Siboglinidae tubeworms from the Storegga Slide. Microbial Ecology, 60(3), 516-527.

Lösekann, T., Robador, A., Niemann, H., Knittel, K., Boetius, A., \& Dubilier, N. (2008). Endosymbioses between bacteria and deepsea siboglinid tubeworms from an artic cold seep (Haakon Mosby Mud Volcano, Barents Sea). Environmental Microbiology, 10(12), $3237-3254$.

Malakhov, V. V., Popelyaev, I. S., \& Galkin, S. V. (1996a). Microscopic anatomy of Ridgeia phaeophiale Jones, 1985 (Pogonophora, Vestimentifera) and the problem of the position of Vestimentifera in the system of animal kingdom. IV. Excretory and reproductive system and coelom. Russian Journal of Marine Biology, 22(5), 249-260.

Malakhov, V. V., Popelyaev, I. S., \& Galkin, S. V. (1996b). Microscopic anatomy of Ridgeia phaeophiale Jones, 1985 (Pogonophora, Vestimentifera) and the problem of the position of Vestimentifera in the system of the animal kingdom. II. Integument, nervous system, connective tissue, and musculature. Russian Journal of Marine Biology, 22(3), 125-136.

Malakhov, V. V., Popelyaev, I. S., \& Galkin, S. V. (1996c). Microscopic anatomy of Ridgeia phaeophiale Jones, 1985 (Pogonophora, Vestimentifera) and the problem of the position of Vestimentifera in the system of the animal kingdom. I. General anatomy, obturacula, and tentacles. Russian Journal of Marine Biology, 22(2), 63-74.

McHugh, D. (1997). Molecular evidence that echiurans and pogonophorans are derived annelids. Proceedings of the National Academy of Sciences, USA, 94, 8006-8009.

Meunier, C., Andersen, A. C., Bruneaux, M., Le Guen, D., Terrier, P., Leize-Wagner, E., et al. (2010). Structural characterization of hemoglobins from Monilifera and Frenulata tubeworms (Siboglinids): first discovery of giant hexagonal-bilayer hemoglobin in the former "Pogonophora" group. Comparative Biochemistry and Physiology. Part A, Molecular \& Integrative Physiology, 155(1), 41-48.

Miglietta, M. P., Hourdez, S., Cowart, D. A., Schaeffer, S. W., \& Fisher, C. (2010). Species boundaries of Gulf of Mexico 
vestimentiferans (Polychaeta, Siboglinidae) inferred from mitochondrial genes. Deep Sea Research Part II: Topical Studies in Oceanography, 57(21-23), 1916-1925.

Nussbaumer, A. D., Fisher, C. R., \& Bright, M. (2006). Horizontal endosymbiont transmission in hydrothermal vent tubeworms. Nature, 441, 345-348.

Palumbi, S. R. (1996). Nucleic acid II: the polymerase chain reaction. In D. M. Hillis, C. Moritz, \& B. K. Mable (Eds.), Molecular systematics (pp. 205-247). Sunderland: Sinauer Associates.

Pedersen, R. B., Rapp, H. T., Thorseth, I. H., Lilley, M. D., Barriga, F. J. A. S., Baumberger, T., et al. (2010). Discovery of a black smoker vent field and vent fauna at the Arctic Mid-Ocean Ridge. Nature Communications, 1(8), 126.

Rouse, G. W. (2001). A cladistic analysis of Siboglinidae Caullery, 1914 (Polychaeta, Annelida): formerly the phyla Pogonophora and Vestimentifera. Zoological Journal of the Linnean Society, $132,55-80$.

Rouse, G. W., \& Fauchald, K. (1997). Cladistics and polychaetes. Zoologica Scripta, 26(2), 139-204.

Rouse, G. W., \& Jamieson, B. G. M. (1987). An ultrastructural study of the spermatozoa of the polychaetes Eurythoe complanata (Amphinomidae), Clymenella sp. and Micromaldane sp. (Maldanidae), with definition of sperm types in relation to reproductive biology. Journal of Submicroscopic Cytology, 19(4), 573-584.

Rouse, G. W., \& Pleijel, F. (2001). Siboglinidae Caullery, 1914. In Polychaetes (pp. 202-205). Oxford: Oxford University Press.

Rouse, G. W., Goffredi, S. K., \& Vrijenhoek, R. C. (2004). Osedax: bone-eating marine worms with dwarf males. Science (Washington), 305(5684), 668-671.

Rouse, G. W., Worsaae, K., Johnson, S. B., Jones, W. J., \& Vrijenhoek, R. C. (2008). Acquisition of dwarf male "harems" by recently settled females of Osedax roseus n. sp. (Siboglinidae; Annelida). The Biological Bulletin, 214, 67-82.

Rouse, G. W., Wilson, N., Goffredi, S., Johnson, S., Smart, T., Widmer, C., et al. (2009). Spawning and development in Osedax boneworms (Siboglinidae, Annelida). Marine Biology, 156(3), 395-405.

Rousset, V., Rouse, G. W., Siddall, M. E., Tillier, A., \& Pleijel, F. (2004). The phylogenetic position of Siboglinidae (Annelida) infered from $18 \mathrm{~S}$ rRNA, 28S rRNA and morphological data. Cladistics, 20, 518-533.

Sahling, H., Galkin, S. V., Salyuk, A., Greinert, J., Foerstel, H., Piepenburg, D., et al. (2003). Depth-related structure and ecological significance of cold-seep communities - a case study from the Sea of Okhotsk. Deep Sea Research Part I: Oceanographic Research Papers, 50(12), 1391-1409.

Sahling, H., Wallmann, K., Dählmann, A., Schmaljohann, R., \& Petersen, S. (2005). The physicochemical habitat of Sclerolinum sp. at Hook Ridge Hydrothermal Vent, Bransfield Strait, Antarctica. Limnology and Oceanography, 50(2), 598-606.

Schulze, A. (2002). Histological and ultrastructural characterization of the intravasal body in Vestimentifera (Siboglinidae, Polychaeta, Annelida). Cahiers de Biologie Marine, 43, 355-358.

Schulze, A. (2003). Phylogeny of Vestimentifera (Siboglinidae, Annelida) inferred from morphology. Zoologica Scripta, 32(4), 321-342.

Smirnov, R. V. (2000). Two new species of Pogonophora from the arctic mud volcano off northwestern Norway. Sarsia, 85, 141-150.

Southward, E. C. (1959). Two new species of pogonophora from the North-east Atlantic. Journal of the Marine Biological Association of the United Kingdom, 38, 439-444.
Southward, E. C. (1961). Pogonophora. In M. Weber (Ed.), SibogaExpeditie (pp. 1-22). Leiden: E. J. Brill.

Southward, E. C. (1972). On some pogonophora from the Caribean and the Gulf of Mexico. Bulletin of Marine Science, 22(4), 739-776.

Southward, E. C. (1975). A study of the structure of the ophistosoma of Siboglinum fiordicum. In A. Norrevang (Ed.), The phylogeny and systematic position of Pogonophora (pp. 64-76). Hamburg Berlin: Verlag Paul Parey.

Southward, E. C. (1988). Development of the gut and segmentation of newly settled stages of Ridgeia (Vestimentifera): implications for relationship betwen Vestimentifera and Pogonophora. Journal of the Marine Biological Association of the United Kingdom, 68, 465-487.

Southward, E. C. (1991). Three new species of Pogonophora, including two vestimentiferans from hydrothermal sites in the Lau Back-arc Basin (Southwest Pacific Ocean). Journal of Natural History, 25, 859-881.

Southward, E. C. (1993). Pogonophora. In F. W. Harrison \& M. E. Rice (Eds.), Microscopic anatomy of invertebrates 12, Onychophora, Chilopoda and Lesser Protostomata (pp. 327-369). New York: Wiley-Liss.

Southward, E. C. (1999). Development of Perviata and Vestimentifera (Pogonophora). Hydrobiologia, 402, 185-202.

Southward, A. J., Southward, E. C., Dando, P. R., Rau, G. H., Felbeck, H., \& Flugel, H. (1981). Bacterial symbionts and low 13C/12C ratios in tissues of Pogonophora indicate unusual nutrition and metabolism. Nature, 293(5834), 616-620.

Southward, E. C., Schulze, A., \& Gardiner, S. (2005). Pogonophora (Annelida): form and function. Hydrobiologia, 535-536(1), 227251.

Southward, E. C., Andersen, A. C., \& Hourdez, S. (2011). Lamellibrachia anaximandri $\mathrm{n}$. sp., a new vestimentiferan tubeworm (Annelida) from the Mediterranean, with notes on frenulate tubeworms from the same habitat. Zoosystema, 33(3), $245-279$.

Tamura, K., Peterson, D., Peterson, N., Stecher, G., Nei, M., \& Kumar, S. (2011). MEGA5: molecular evolutionary genetics analysis using maximum likelihood, evolutionary distance, and maximum parsimony methods. Molecular Biology and Evolution, 28(10), 2731-2739.

van der Land, J., \& Norrevang, A. (1977). Structure and relationships of Lamellibrachia (Annelida, Vestimentifera). Kongelige Danske Videnskabernes Selskab Biologiske Skrifter, 21(3), 1-102.

Webb, M. (1964a). Evolutionary paths within the phylum Pogonophora. Sarsia, 16(59), 64.

Webb, M. (1964b). Additional notes on Sclerolinum brattstromi (Pogonophora) and the establishment of a new family, Sclerolinidae. Sarsia, 16, 47-58.

Webb, M. (1964c). A new bitenticulate pogonophoran from Hardangerfjorden, Norway. Sarsia, 15, 49-55.

Webb, M. (1977). Studies on Lamellibrachia barhami (Pogonophora). II. The reproductive organs. Zoologische Jahrbucher - Abteilung für Anatomie und Ontogenie der Tiere, 97, 455-481.

Webb, M., \& Ganga, K. S. (1980). Studies on Lamellibrachia barhami (Pogonophora) III. Plaques, glands and epidermis. Annale Uniiversiteit van Stellenbosch Serie A2 (Soölogie), 2, 1-27.

Zrzavý, J., Riha, P., Pialek, L., \& Janouskovec, J. (2009). Phylogeny of Annelida (Lophotrochozoa): total-evidence analysis of morphology and six genes. BMC Evolutionary Biology, 9(189), 1-14. 